\title{
Non-financial reporting formats in public sector organizations: a structured literature review
}

\author{
Francesca Manes-Rossi \\ Department of Economics Management and Institutions, \\ University of Naples Federico II, Naples, Italy \\ Giuseppe Nicolò \\ Department of Management and Innovation Systems, University of Salerno, \\ Fisciano, Italy, and \\ Daniela Argento \\ Department of Business, Kristianstad University, Kristianstad, Sweden
}

\begin{abstract}
Purpose - Research dealing with non-financial reporting formats in public sector organizations is progressively expanding. This paper systematizes the existing literature with the aim of understanding how research is developing and identifying the gaps in need of further investigation.

Design/methodology/approach - A structured literature review was conducted by rigorously following the steps defined in previous studies. The structured nature of the literature review paves the way for a solid understanding and critical analysis of the state of the art of research on non-financial reporting formats in public sector organizations.

Findings - The critical analysis of the literature shows that most existing studies have focused on sustainability reporting in higher education institutions, local governments and state-owned enterprises, while remaining silent on the healthcare sector. Additional theoretical and empirical approaches should feed future research. Several areas deserve further investigations that might impactfully affect public sector organizations, standard setters, practitioners and scholars.

Originality/value - This paper offers a comprehensive review of the literature on different reporting formats that public sector organizations adopt to report various dimensions of their performance to both internal and external stakeholders. The structured literature review enables the identification of future directions for the literature in this field.
\end{abstract}

Keywords Sustainability reporting, Integrated reporting, Popular reporting, Non-financial reporting,

Structured literature review

Paper type Literature review

\section{Introduction}

Studies on non-financial reporting formats developed by public sector organizations (PSOs) are progressively increasing in number. PSOs are experiencing accountability pressure from stakeholders due to their pivotal role in society (Almqvist et al., 2013). They engage in

(C) Francesca Manes-Rossi, Giuseppe Nicolò and Daniela Argento. Published by Emerald Publishing Limited. This article is published under the Creative Commons Attribution (CC BY 4.0) licence. Anyone may reproduce, distribute, translate and create derivative works of this article (for both commercial and non-commercial purposes), subject to full attribution to the original publication and authors. The full terms of this licence may be seen at: http://creativecommons.org/licences/by/4.0/legalcode

While the paper is the result of a joint effort of the authors, the individual contributions are as follows: Francesca Manes-Rossi wrote: 1. Introduction; 4.1 Public sector focus; 4.2 Country of research; 4.3 Focus on type of reports; 4.7 Academics and practitioners. Giuseppe Nicolò wrote: 2. Methodology; 4.4. Focus of literature; 4.5 Methods adopted; 4.6 Reporting frameworks and models. Daniela Argento wrote: 3. Development of research on non-financial reporting formats in public sector organizations; 5 . Nonfinancial reporting formats: a critical summary and future research agenda; 6 . Concluding remarks.

Non-financial reporting formats in

PSOs

Received 20 March 2020 Revised 12 June 2020 30 June 2020 Accepted 1 July 2020 
JPBAFM 32,4

\section{0}

sustainable development and are stewards of social and environmental issues (Farneti and Siboni, 2011; Greiling et al., 2015; Kaur and Lodhia, 2019). PSOs are expected to deliver services and create public value in compliance with the principles of economic, environmental and social sustainability (Argento et al., 2020; Farneti et al., 2019a; Kaur and Lodhia, 2019). Such expectations refer to various PSOs, including - among others-national and local governments, state-owned enterprises, higher education and healthcare institutions. Sustainability entails responsibilities for long-term value creation and is not always compatible with the information provided via traditional financial reports (Argento et al., 2019a). Research has shown how PSOs have begun to provide non-financial disclosure through various types of non-financial reports, such as sustainability reports (SRs), popular reports (PRs), integrated reports (IRs), webpages or social media, in order to meet stakeholders' expectations and ensure adequate levels of accountability (Andrades Peña and Larrán Jorge, 2019; Iacuzzi et al., 2020; Manes-Rossi et al., 2020).

Recently, Kaur and Lodhia (2019) have called for more research exploring the paths of social and environmental accounting, accountability and reporting practices in the public sector to enhance the understanding of the role PSOs are playing in advancing the nonfinancial accounting, accountability and reporting agenda. To address this call, a rigorous and systematic literature review may be beneficial to both enhance knowledge on nonfinancial reporting formats adopted in the public sector and inform policymaking and practice (Tranfield et al., 2003). A structured literature review (SLR) is particularly important because it is "a method for studying a corpus of scholarly literature, to develop insights, critical reflections, future research paths and research questions" (Massaro et al., 2016, p. 767). A critical review of the existing literature that examines relative strengths and weaknesses can identify the state of the art, map the evolution of non-financial reporting formats in PSOs and uncover issues and topics that are still unexplored.

In line with previous studies dealing with SLR methodology (Tranfield et al., 2003; Guthrie et al., 2012; Dumay et al., 2016; Massaro et al., 2016; Bisogno et al., 2018; Bracci et al., 2019), this paper develops an SLR with the aim of answering the following research questions:

$R Q 1$. What trends and themes can be identified in the existing literature on non-financial reporting formats in the public sector?

$R Q 2$. What are the main gaps in the current research on non-financial reporting formats in public sector organizations?

The remainder of the paper is structured as follows. The next section explains the methodology that was adopted to conduct the SLR. Section 3 introduces the evolution of research dealing with non-financial reporting formats in PSOs. Section 4 answers the first RQ by providing an analysis of the papers included in the SLR. Section 5 addresses the second RQ by critically discussing the findings and outlining future research directions. Section 6 concludes and identifies the study's limitations.

\section{Methodology}

An SLR is a suitable research method to answer the RQs of this study, as it allows the depiction of the landscape of current research on non-financial reporting formats in the public sector from the perspective of past studies (Tranfield et al., 2003; Bracci et al., 2019; Santis et al., 2018). An SLR enables a critical examination and evaluation of existing studies through the lens of specific research themes. It leads to the identification of gaps, offering new insights and paths for future research agendas (Dumay et al., 2016; Massaro et al., 2016; Bracci et al., 2019).

An SLR is different from a traditional narrative review in which "the researcher summarizes and interprets previous contributions in a subjective and narrative fashion" 
(Denyer and Tranfield, 2006, p. 216), providing insights based on their knowledge and expertise on the selected issue. An SLR is grounded in a rigorous procedure based on a logical structure and on a well-defined, replicable and transparent investigation process (Tranfield et al., 2003; Massaro et al., 2016; Bisogno et al., 2018). Such rigor minimizes errors and biases arising from subjective analysis and judgments (Tranfield et al., 2003).

Given that an SLR is a "fundamental scientific activity" that provides high-quality results (Mulrow et al., 1997, p. 597), SLRs have gained prominence in accounting studies (Britten et al., 2002; Massaro et al., 2016). This is also the case in the public sector accounting domain, in which different studies exploring non-financial reporting formats in different countries and political contexts are emerging.

Inspired by previous studies (Guthrie et al., 2012; Dumay et al., 2016; Massaro et al., 2016; Bisogno et al., 2018), the SLR conducted in this study is based on a structured process involving the five steps described below.

\subsection{Literature research and sample development}

The first step involved the search of scientific articles to be included in the literature review. This step was based on certain criteria to ensure the identification of contributions that meet the research objectives (Massaro et al., 2016; Bisogno et al., 2018). To start the search, the following keywords were used: ((("integrated report”) OR ("integrated thinking”) OR (“sustainability report”) OR ("popular report”) OR (“social report”)) AND ((“universit*”) OR ("public sector") OR ("government”) OR ("healthcare") OR ("state-owned enterprise”) OR ("hybrid”) OR ("utilities"))). Two databases were selected as data sources: Scopus and ISI Web of Science. The search was launched on July 1,2019, with some restrictions. The research field was limited to contributions related to social science, business management and accounting that were published (or accepted for publication) in the period ranging from 2002 to 2019. In addition, only scientific articles written in English and published in peer-reviewed journals were searched for. This choice was made to ensure that the SLR covered high-quality research that had already been subjected to peer review. Books, book chapters, editorials, conference papers, reports and other contributions were excluded.

The database search retrieved 2,426 contributions. To identify and exclude duplicates, a manual search was conducted by inspecting the list of contributions. After removing 54 duplicates, the dataset included 2,372 contributions.

The second step consisted of assessing the relevance (Petticrew and Roberts, 2008) of the retrieved contributions. Each contribution was inspected by carefully examining its title and abstract and, whenever necessary, its contents, following a set of predefined criteria. First, the contributions had to focus on non-financial reporting formats in the public sector. Articles on non-financial reporting formats in private sector organizations, such as listed companies, small and medium enterprises, banks, cooperatives, charities and not-for-profit organizations, were excluded. Second, despite the strict search criteria depicted above (see first step), the contributions were screened to ensure that they were scientific articles published in peer-reviewed journals. After the screening, 1,783 contributions were excluded because they were focused on other research fields (e.g. financial reporting and management control) or were books or book chapters, while another 518 contributions were removed due to their focus on non-financial reporting formats in private firms. In addition, only articles published in journals included in the SCImago Journal Rank were included in the sample. Thus, another five articles were excluded, resulting in a sample of 66 scientific articles.

A third step was considered necessary to complement the selection process and obtain a more representative sample. A manual search was performed in the main journals publishing public sector accounting articles (see Table 1) by inspecting each number and issue published from 2010 to January 28, 2020. This search led to the addition of 20 articles.
Non-financial reporting formats in

PSOs 


\section{JPBAFM} 32,4

\section{2}

Administration and Society

American Review of Public Administration

Australian Journal of Public Administration

Government Information Quarterly

International Journal of Public Administration

International Journal of Public Sector Management

International Public Management Journal

International Review of Administrative Sciences

International Review of Public Administration

Journal of Public Administration Research and Theory

Journal of Public Budgeting Accounting and Financial Management

Local Government Studies

Public Administration

Table 1.

List of journal for additional research
Public Administration Review

Public Management Review

Public Money and Management

Finally, five more articles that had been published in the 2019 special issue on "Accounting, Accountability and Reporting in the Public Sector" of the journal Meditari Accountancy Research were added because they were coherent with the scope of the SLR.

The final sample of scientific articles reviewed in this study consists of 91 articles. Table 2 illustrates the database development process (Table 2).

The 91 scientific articles were downloaded and a digital archive was created for subsequent analyses. The reference list in the end of this paper lists with * the articles included in the literature review.

\subsection{The analytical framework and coding activity}

The fourth step consisted of the development of an analytical framework - that is, the tool used to categorize and analyze the 91 scientific articles included in the final sample. According to Krippendorff (2013, p. 98), researchers have to settle "what is to be observed as well as how observations are to be recorded and thereafter considered data." Researchers must determine the unit of analysis, in terms of aspects to be analyzed and information to be collected in the articles (Massaro et al, 2016). The analytical framework adopted in this SLR is based on the well-established frameworks developed by Guthrie et al. $(2012)$, Dumay et al. $(2015,2016)$ and Bisogno et al. (2018). However, some adaptations were made to obtain a framework that was coherent with the research objectives and peculiarities of this SLR. Since this study is specifically focused on PSOs, the analytical framework consists of seven categories: (A) public sector focus, (B) country of research, (C) focus on types of reports, (D) focus of literature, (E) research methods, (F) reporting frameworks and models and $(\mathrm{G})$ academics and practitioners.

Category (A), "public sector focus", is an adaptation of the categories "jurisdiction" (Guthrie et al., 2012; Dumay et al., 2015), "educational context" (Bisogno et al., 2018) and

(1) Keyword search (Scopus 2,171 + ISI 255-54 duplicates)

(2) Contributions concerning other fields and/or book (chapters)

(3) Contributions concerning private firms

$-1,783$

(4) Articles published in non-Scimago journals

$-518$

(5) Relevant articles

(6) Articles added from an additional search

Table 2.

Final sample 
"organizational focus" (Dumay et al., 2016). It includes the following sub-categories: (A1) central government, (A2) state/regional government, (A3) local government, (A4) state-owned enterprises, (A5) healthcare institutions, (A6) educational institutions, (A7) other and (A8) general.

Category (B), "country of research", was obtained by slightly amending the category previously developed by Dumay et al. (2015). It includes nine sub-categories: (B1) Europe/UK, (B2) Oceania, (B3) North America, (B4) South America, (B5) Africa, (B6) Asia, (B7) worldwide (added to code studies focused on PSOs located in different countries), (B8) none (added to consider conceptual studies not analyzing any specific country) and (B9) mixed.

As this SLR focuses on non-financial reporting formats from a public sector perspective, category (C), "focus on type of reports", was added. This category includes the different types of communication tools investigated in selected articles: (C1) Sustainability Report, (C2) Popular Report, (C3) Integrated Report, (C4) webpages/social media, (C5) mixed reports (for coding articles covering multiple types of reports) and (C6) others (a residual sub-category used to code articles focusing on other type of reports, e.g. strategic plans, management commentaries or mission statements).

Category (D), "focus of literature", is based on the work of Guthrie et al. (2012) and Dumay et al. (2015) and consists of five sub-categories: (D1) external reporting, (D2) auditing and assurance, (D3) accountability and governance, (D4) management control/strategy and (D5) other.

Categories (E) "research methods", (F) "reporting frameworks and models" and (G) "academics and practitioners" were also inspired by the work of Guthrie et al. (2012), Dumay et al. (2015; 2016) and Bisogno et al. (2018).

The fifth step took place once the analytical framework was finalized. The authors coded the 91 scientific articles, analyzed the data and wrote the results and interpretations.

\subsection{Developing reliability}

Different measures were adopted during the steps of the SLR to minimize subjectivity biases that can influence the analysis, in order to ensure the reliability of the study (Tranfield et al., 2003; Krippendorff, 2013).

During the second step, the 2,372 contributions that had been retrieved from the two databases were equally divided among the three authors, who independently analyzed titles and abstracts - and, whenever necessary, content - in order to assess their relevance (Petticrew and Roberts, 2008). Several meetings were held to jointly solve uncertainties and discuss articles whose relevance was doubtful.

In the third step, the additional search of relevant articles in the journals listed in Table 1 and in the special issue of Meditari Accountancy Research was conducted by one of the authors over a short period of time (two weeks in January 2020) to ensure intra-coder reliability.

In order to lend reliability to the fourth step, the authors jointly determined the categories included in the analytical framework. Given the importance of the categories being "defined in such a way that different people, working independently, will make the same judgements when using the same material" (Lakshman, 2012, p. 482), the three authors conducted a pilot study. Each author independently tested the analytical framework on 30 articles and then compared/discussed their results. The categories that were mostly discussed were (A) public sector focus, (B) country of research, (C) types of reports, (D) focus of literature and (E) research methods. The authors reached the necessary consensus on the definition and meaning of each category, and revised the framework to improve its suitability. Achieving consensus is important to ensure inter-coder reliability when multiple researchers are involved in the coding of articles. 
JPBAFM 32,4

\section{4}

In the fifth step, each of the three authors independently proceeded with the manual coding of the articles they were assigned. Manual coding avoids the problems encountered by software in the analysis of ambiguous or similar terms, allowing for more accurate and effective coding (Guthrie et al., 2012; Massaro et al., 2015). The coding activity was recorded in an Excel file to facilitate subsequent analysis. Finally, two authors made a final check to agree on the sub-categories assigned to the 91 articles. Since agreement had been achieved in a step-by-step manner, the authors considered it superfluous to carry out formal reliability checking, such as Krippendorff's alpha (Krippendorff, 2013).

\section{Development of research on non-financial reporting formats in public sector organizations}

Figure 1 shows the distribution of articles in the period 2010-2019 and indicates that research on non-financial reporting formats in PSOs displays a growing trend, with a significant increase from 2017 onwards.

Table 3 presents the number of articles per source journal. Journals from which fewer than two articles were retrieved are referred to as "others." The journal with the greatest number of relevant articles is IJSHE (11), which underlines the importance of higher education in the public sector domain. Moreover, the presence of internationally recognized generalist accounting journals, such as MEDAR (8), JCP (3) and JIC (3), indicates that public sector studies are gradually spreading worldwide, going beyond specialist journals such as IJSHE, PMM or PMR. This interest can be considered as a consequence of the importance of nonfinancial topics such as sustainability and social, environmental and intangible issues in the public sector.

An analysis of the number of citations provides a clear picture of the articles and authors that have exerted a decisive influence in a specific research field (Garfield, 1977). In line with Massaro et al. (2016), the impact of each of the 91 articles was measured by the number of Google Scholar citations as of January 28, 2020.

Table 4 lists the top ten articles based on the number of citations.

Older articles are often better known and consolidated in the literature because they have had a longer time span to receive citations, in comparison with newer articles (Dumay, 2014; Dumay et al., 2016). A second ranking based on the average number of citations per year (CPY) can mitigate this problem (Dumay et al., 2016; Bisogno et al., 2018) by comparing the
Figure 1.

Number of articles per year (2010-2019)

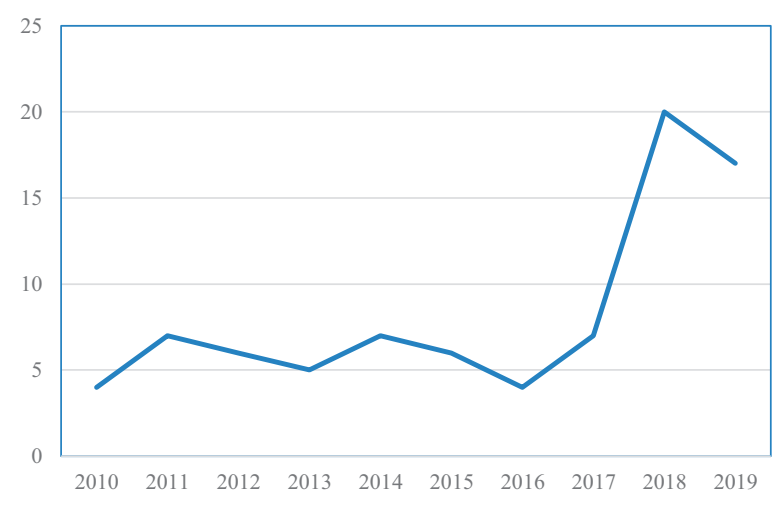




\begin{tabular}{llr}
\hline Code & Journal name & No \\
\hline IJSHE & International Journal of Sustainability in Higher Education & 11 \\
PMM & Public Money and Management & 9 \\
PMR & Public Management Review & 9 \\
MEDAR & Meditari Accountancy Research & 9 \\
IJPSM & International Journal of Public Sector Management & 4 \\
AAAJ & Accounting, Auditing and Accountability Journal & 3 \\
JCP & Journal of Cleaner Production & 3 \\
JIC & Journal of Intellectual Capital & 3 \\
LGS & Local Government Studies & 3 \\
AF & Accounting Forum & 2 \\
GIQ & Government Information Quarterly & 2 \\
IJPA & International Journal of Public Administration & 2 \\
JPBAFM & Journal of Public Budgeting, Accounting and Financial Management & 2 \\
LL & Lex Localis & 2 \\
SUST & Sustainability & 2 \\
OTH & Others & 25 \\
& Total & 91 \\
\hline
\end{tabular}

Non-financial reporting formats in PSOs

645

\begin{tabular}{|c|c|c|c|c|}
\hline No & Reference & Article & Cit & \\
\hline 1 & Rahaman et al. (2004) & $\begin{array}{l}\text { Social and environmental reporting at the VRA: institutionalized } \\
\text { legitimacy or legitimation crisis }\end{array}$ & 358 & \\
\hline 2 & Lozano (2011) & The state of sustainability reporting in universities & 307 & \\
\hline 3 & Guthrie and Farneti (2008) & $\begin{array}{l}\text { GRI Sustainability Reporting by Australian Public Sector } \\
\text { Organizations }\end{array}$ & 279 & \\
\hline 4 & Dumay et al. (2010) & $\begin{array}{l}\text { GRI Sustainability Reporting Guidelines for Public and Third } \\
\text { Sector Organizations }\end{array}$ & 251 & \\
\hline 5 & Ball (2005) & Environmental accounting and change in UK local government & 209 & \\
\hline 6 & $\begin{array}{l}\text { Marcuccio and Steccolini } \\
(2005)\end{array}$ & $\begin{array}{l}\text { Social and environmental reporting in local authorities: a new } \\
\text { Italian fashion? }\end{array}$ & 168 & \\
\hline 7 & Fonseca et al. (2011) & The state of sustainability reporting at Canadian universities & 162 & \\
\hline 8 & Frost and Seamer (2002) & $\begin{array}{l}\text { Adoption of environmental reporting and management } \\
\text { practices: an analysis of New South Wales public sector entities }\end{array}$ & 149 & \\
\hline 9 & Williams et al. (2011) & $\begin{array}{l}\text { Sustainability reporting by local government in Australia: } \\
\text { current and future prospects }\end{array}$ & 101 & $\begin{array}{l}\text { Top ten cited articles } \\
\text { by Google Scholar }\end{array}$ \\
\hline 10 & $\begin{array}{l}\text { Larrinaga-Gonzélez and } \\
\text { Pérez-Chamorro (2008) }\end{array}$ & $\begin{array}{l}\text { Sustainability accounting and accountability in public water } \\
\text { companies }\end{array}$ & 94 & $\begin{array}{r}\text { citations (as of } 28 \\
\text { January 2020) }\end{array}$ \\
\hline
\end{tabular}

citations of older articles versus newer ones more fairly (Dumay, 2014). Table 5 lists the top 10 articles according to CPY.

Six articles appear in both tables (Rahaman et al., 2004; Ball, 2005; Guthrie and Farneti, 2008; Dumay et al., 2010; Fonseca et al., 2011; Lozano, 2011) showing that few articles among the first studies investigating voluntary sustainability reporting practices in public sector dominate the literature. An emerging research agenda on non-financial reporting formats in the public sector is also evident, considering the presence in Table 5 of more recent articles (Domingues et al., 2017; Niemann and Hoppe, 2018; Sangiorgi and Siboni, 2017; Yáñez et al., 2019) that have gained a relatively higher number of citations during a short time period. 


\begin{tabular}{|c|c|c|c|c|}
\hline \multirow{4}{*}{$\begin{array}{l}32,4 \\
32\end{array}$} & No & Reference & Article & $\mathrm{CPY}$ \\
\hline & 1 & Lozano (2011) & The state of sustainability reporting in universities & 34.1 \\
\hline & 2 & Dumay et al. (2010) & $\begin{array}{l}\text { GRI Sustainability Reporting Guidelines for Public and Third Sector } \\
\text { Organizations }\end{array}$ & 25.1 \\
\hline & 3 & $\begin{array}{l}\text { Guthrie and Farneti } \\
(2008)\end{array}$ & GRISustainability Reporting by Australian Public Sector Organizations & 23.2 \\
\hline \multirow[t]{5}{*}{646} & 4 & Rahaman et al. (2004) & $\begin{array}{l}\text { Social and environmental reporting at the VRA: institutionalized } \\
\text { legitimacy or legitimation crisis }\end{array}$ & 22.4 \\
\hline & 5 & Fonseca et al. (2011) & The state of sustainability reporting at Canadian universities & 18.0 \\
\hline & 6 & $\begin{array}{l}\text { Sangiorgi and Siboni } \\
\text { (2017) }\end{array}$ & The disclosure of intellectual capital in Italian universities & 17.0 \\
\hline & 7 & $\begin{array}{l}\text { Niemann and Hoppe } \\
\text { (2018) }\end{array}$ & $\begin{array}{l}\text { Sustainability reporting by local governments: a magic tool? Lessons on } \\
\text { use and usefulness from European pioneers }\end{array}$ & 15.0 \\
\hline & 8 & Yanez et al. (2019) & $\begin{array}{l}\text { The sustainability report as an essential tool for the holistic and } \\
\text { strategic vision of higher education institutions }\end{array}$ & 15.0 \\
\hline \multirow{2}{*}{$\begin{array}{l}\text { Table } 5 \text {. } \\
\text { Top ten cited articles } \\
\text { by citation per year } \\
\text { (CPY) (as of } 28 \\
\text { January 2020) }\end{array}$} & 9 & $\begin{array}{l}\text { Domingues et al. } \\
\text { (2017) }\end{array}$ & $\begin{array}{l}\text { Sustainability reporting in public sector organizations: Exploring the } \\
\text { relation between the reporting process and organizational change } \\
\text { management for sustainability }\end{array}$ & 14.0 \\
\hline & 10 & Ball (2005) & Environmental accounting and change in UK local government & 13.9 \\
\hline
\end{tabular}

\section{Research on non-financial reporting formats: insights and critiques}

Table 6 presents the results from coding the 91 articles according to the analytical framework.

\subsection{Public sector focus}

The first category concerns the types of PSO referred to in each article. As Figure 2 shows, most of the articles deal with educational institutions-more specifically, with higher education institutions (HEIs) (30\%) —or local governments (LGs) $(30 \%)$, followed by SOEs $(14 \%)$. Academics have devoted less attention to non-financial reporting formats adopted by central governments and state or regional governments $(7 \%$ in total) and healthcare institutions (only 3\%). The articles included in the group "others" $(5 \%)$ are related to sustainability reporting. While three of these articles are global (Domingues et al., 2017) or related to a specific country (Guthrie and Farneti, 2008; Cotterell and Crothers, 2011), the other two consider specific entities that are generally not addressed by scholars (Rahaman et al., 2004; Bergmans et al., 2014). The articles coded as "general" (10\%) generically address nonfinancial reporting formats. Apart from one SLR article on social and environmental accounting research in the public sector (Fusco and Ricci, 2019), most of these articles discuss the motivations that lead PSOs to adopt SRs and the usefulness of such reports (Frost and Seamer, 2002; Larrinaga et al., 2018; Mussari and Monfardini, 2010; Uyar et al., 2019), or consider the frameworks to be adopted (Dumay et al., 2010). Few articles discuss the pros and cons of the different non-financial reporting formats (Biondi and Bracci, 2018; Manes-Rossi, 2019) or introduce new formats (Cohen and Karatzimas, 2015).

Considering the distribution of articles, it seemed worthwhile to focus on the three most observed typologies of PSOs.

4.1.1 Educational institutions. The research dealing with the non-financial reporting formats adopted by PSOs operating in the field of education confirms scholars' great interest in sustainability reporting. More specifically, all articles included in this SLR deal with HEIs, while other kind of institutions has not been considered, thus indicating a further gap in the literature. The majority of the articles (20 out of 27) discuss the adoption of SRs, while two (Adams, 2018; Veltri and Silvestri, 2015) consider the adoption of IRs and one (Seibert and Macagnan, 2019) investigates sustainability disclosure provided through the web. Only two 


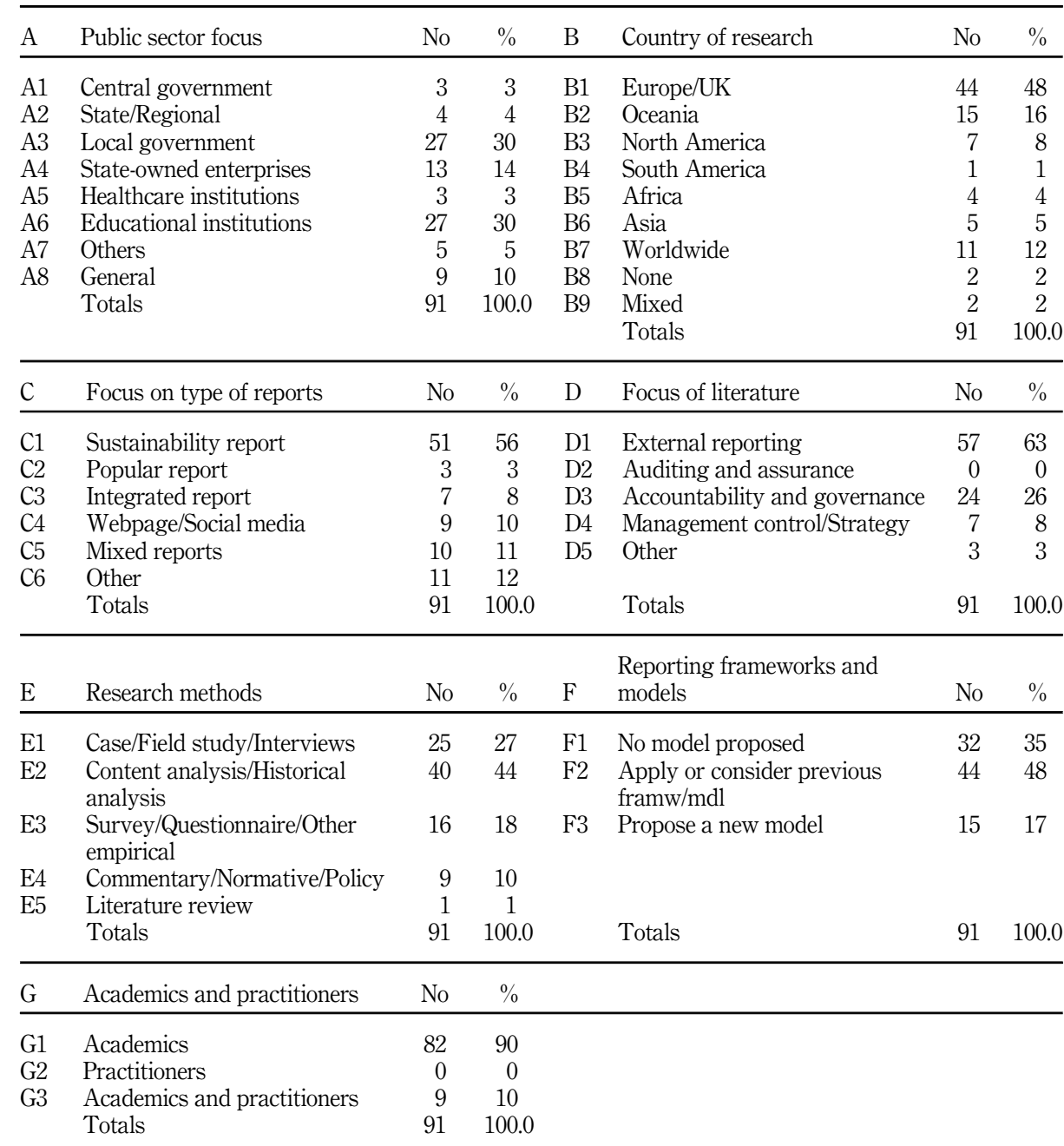

Source(s): Categories adapted from Guthrie et al. (2012), Dumay et al. (2015; 2016) and Bisogno et al. (2018), and compiled by the authors
Non-financial reporting formats in

PSOs

647
Analytical framework of non-financial reporting formats in public sector

articles investigate a mixed form of reports - namely, integrated SRs (Brusca et al., 2018; Kräusche and Pilz, 2018). Another two articles respectively examine sustainability information provided through annual reports (Schaffhauser-Linzatti and Ossmann, 2018) and mission statements (Lopez and Martin, 2018). Thus, even when different reporting tools are examined, the focus is mainly on sustainability issues. Scholars contend that sustainability reporting in HEIs is still at an early stage, even though some of the analyzed contexts (e.g. Anglo-Saxon countries) can be considered to be early adopters of sustainability practices (e.g. Lopatta and Jaeschke, 2014; Sepasi et al., 2019).

Scholars discuss non-financial reporting formats in HEIs by making use of different methods, although research through a content analysis of published reports or webpages prevails (16 articles out of 27 ). 


\section{JPBAFM 32,4}

\section{8}

Figure 2.

Articles distribution per type of public sector organization $(\%)$

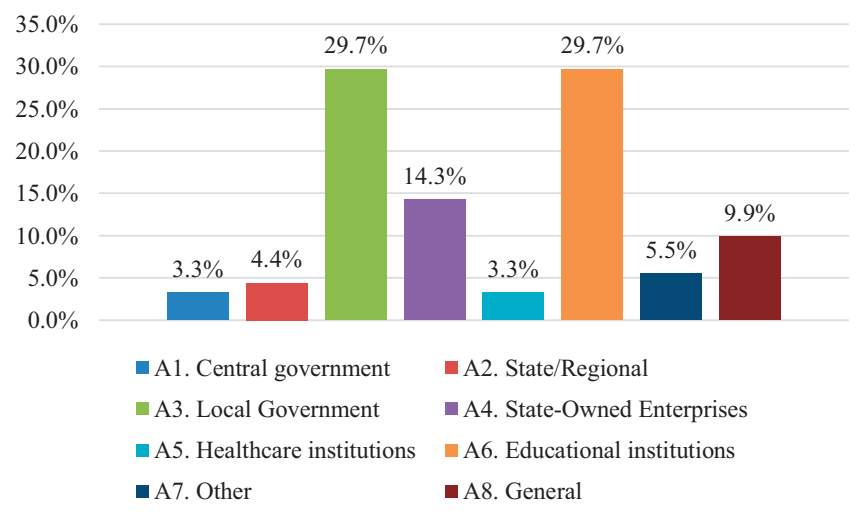

An interesting result is that, even if some commonalities exist in reporting non-financial information, country-specific factors can create differences. For example, Australian (Gamage and Sciulli, 2017), Canadian (Fonseca et al., 2011), New Zealand (An, 2017), UK (Sassen et al., 2018) and US (Sassen and Azizi, 2018) HEIs mainly focus on environmental issues, while Lopatta and Jaeschke (2014) reveal that German and Austrian HEIs equally focus on environmental, economic and educational dimensions. Their results are confirmed by the German case study analyzed by Kräusche and Pilz (2018). Sustainability exerts a strong impact on research and teaching activities (Fonseca et al., 2011) and changes in policies are mainly driven by institutional changes (Siboni et al., 2013; Yáñez et al., 2019).

Many studies dealing with sustainability reporting in HEIs consider the Global Reporting Initiative (GRI) guidelines as a point of reference, as most HEIs use GRI indicators in their reports (e.g. Lozano, 2011; Lopatta and Jaeschke, 2014; Ferrero-Ferrero et al., 2018; Sepasi et al., 2019). However, scholars also recognize that the lack of an educational institutions category within GRI guidelines impedes a full assessment of the core competences of HEIs.

An overview of the literature reveals the need for specific guidelines. As Adams (2018) emphasizes, HEIs have the potential to be extremely influential on sustainable development issues, in part because students educated in the promotion of SDGs can be a "force for change." It is possible that stronger recommendations by high-level institutions and the development of specific guidelines supporting HEIs can stimulate an advancement in sustainability policies and-consequently - in reporting.

4.1.2 Local government. Issues related to sustainability in LGs have attracted the attention of scholars all over the world. Most of the articles discussing non-financial reporting formats in LGs (11 out of 27) touch upon SRs (e.g. Ball, 2005; Farneti and Siboni, 2011; Williams et al., 2011; Giacomini et al., 2018; Niemann and Hoppe, 2018). The growing number of articles dealing with SRs in LGs can be explained by the pivotal role played by LGs in promoting the sustainable development agenda at the local level. LGs have high proximity with citizens, and SRs are crucial tools to foster policymaking, citizen engagement and the broader accountability discourse (Williams et al., 2011; Giacomini et al., 2018; Niemann and Hoppe, 2018).

Growing attention has been dedicated to disclosure that is provided through the web $(8$ articles out of 27), as a suitable tool to support transparency. This strand of research strongly focuses on the role that socio-economic and cultural dimensions play in disclosure that is provided both for sustainability issues (Alcaraz-Quiles et al., 2014, 2015; Joseph et al., 2014; Navarro-Galera et al., 2016; Hossain, 2018; Ortiz-Rodríguez et al., 2018; Ruiz-Lozano et al., 2019) and, more broadly, for social, financial and environmental information (Frias-Aceituno et al., 2013). All the studied authors converge toward the same claim: that environmental 
issues are barely considered in LGs' webpages. Cultural and social features strongly affect transparency, while fiscal pressure is inversely associated with the discussion of sustainability issues (Alcaraz-Quiles et al., 2015)

A different reporting format - the PR-which was specifically conceived for LGs and emerged in the United States in the early 2000s, seems to have attracted a resurgence of interest in the last few years, despite its scant application in other continents (Jordan et al., 2017; Cohen et al., 2017; Manes-Rossi et al., 2019). The lack of specific guidelines and strong institutional pressure, however, prevents a larger diffusion of this tool, even though it might be particularly suitable to open a dialogue with citizens due to its simplicity.

Researchers have also studied other kinds of reports that LGs can prepare to satisfy different information needs or legal requirements. Del Bello (2006) examines Local Agenda 21 as a possible report through which LGs can disseminate information related to intangibles and sustainability issues. Marcuccio and Steccolini (2009) analyze performance reporting in Italian LGs and reveal a high level of disclosure of social issues. Both Mazzara et al. (2010) and Sangiorgi et al. (2017) consider strategic plans, respectively in Italian and European LGs, and discover a low level of sustainability disclosure. Che Ku Kassim et al. (2019) report that Malaysian LGs use environmental reporting as a legitimacy tool. However, the lack of skilled staff limits the production of environmental information.

All in all, research investigating non-financial reporting formats by LGs reveals that contextual factors matter in the disclosure of social and environmental information. In addition, environmental disclosure is still in its infancy due to the lack of legal requirements and the relative pressure exerted by international guidelines such as the GRI.

4.1.3 State-owned enterprises. The use of non-financial reporting formats by SOEs is attracting increasing scholarly attention. Almost $70 \%$ of the selected articles were published in the last five years. Although the interest in sustainability reporting remains prevalent (8 articles out of 13), there is also an interest in integrated reporting (Montecalvo et al., 2018; Farneti et al., 2019a; Tirado-Valencia et al., 2019).

Beyond the tools adopted for non-financial disclosure, research focusing on SOEs confirms a trend common to all PSOs. That is, SOEs place strong emphasis on environmental issues (Larrinaga-Gonzélez and Pérez-Chamorro, 2008; Samkin, 2012; Greiling et al., 2015), especially when mandatory rules exist (Bae, 2014) or institutional pressure are exercised by peer institutions (Zhao and Patten, 2016) or the social and legal environment (Montecalvo et al., 2018).

Garde Sánchez et al. (2017) report that size, sector and government ownership exert a positive influence on the sustainability disclosure of Spanish SOEs. Furthermore, corporate governance characteristics (e.g. age, older managers and female managers) may also lead to increased sustainability disclosure. These results are partially confirmed by Andrades Peña and Larrán Jorge (2019), who, upon examining the extent of mandatory non-financial information disclosed through both webpages and reports, found that size and profitability exert a positive influence.

Only one article investigated the quality of disclosure (Kansal et al., 2018), revealing a prevalence of narrative information rather than quantitative/monetary disclosure.

It is also interesting to note the effects produced by the adoption of integrated reporting in enhancing SOEs' accountability. Montecalvo et al. (2018) and Farneti et al. (2019a) provide evidence through a case study of the increased accountability promoted by a materiality assessment approach, particularly for social matters. Tirado-Valencia et al. (2019) investigated whether and how integrated thinking is permeating IR. Their results show a progressive increase in the adoption of integrated thinking, particularly in the "governance" dimension.

Vinnari and Laine (2013) found that the initial explosion of information on environmental issues disclosed by Finnish SOEs operating in the water sector was the result of a temporary fad, while organizational factors and the lack of external pressures led to a decline of this
Non-financial reporting formats in

PSOs 
JPBAFM 32,4

\section{0}

Figure 3.

Articles distribution per country of research (nr.) disclosure. Understanding what drives public managers to provide information is fundamental in supporting companies in enhancing their disclosure.

The analysis clearly displays scholars' interest in the adoption of sustainability policies and reporting in PSOs, regardless of the format this kind of disclosure may assume. To this end, the need emerges for guidelines and standards specifically developed to accommodate the distinctive features of PSOs.

\subsection{Country of research}

Concerning the second category, "country of research," 44 articles (out of 91) deal with nonfinancial reporting formats of PSOs located in Europe and the UK This trend may be the consequence of the European Directive 95/2014, which asks all large entities to provide additional non-financial information in their reports. It is worth noticing that 17 articles examining European practices are related to Italian PSOs, while 10 deal with the Spanish context. These results confirm the interest of Italian and Spanish scholars in non-financial reporting formats, as noted by Bisogno et al. (2018). The empirical focus on Italy and Spain might be motivated by the transparency legislation issued in both countries, as well as the pressure exercised by Italian national guidelines to support the development of sustainability reporting in Italy (i.e. the GBS guidelines).

Research dealing with Oceania's PSOs also seems to be well established (15 articles), covering different kinds of organizations and spanning the entire period covered by this SLR. It is also interesting to note that 11 articles $(12 \%)$ embrace a global perspective. Five of these articles consider the GRI as a point of reference (Dumay et al., 2010; Bice and Coates, 2016; Ferrero-Ferrero et al., 2018; Romolini et al., 2015; Uyar et al., 2019), confirming the relevance of these guidelines in supporting the sustainability disclosure of organizations interested in enhancing accountability, despite their generalist approach.

Figure 3 shows that some geographical areas have received less attention so far. Only one article investigates South America (Seibert and Macagnan, 2019), four focus on Africa and five examine Asia.

\subsection{Focus on type of reports}

In relation to the third category, "focus on type of reports," Figure 4 shows the distribution of 83 articles in the period 2010-2019 in relation to the different formats of non-financial reports

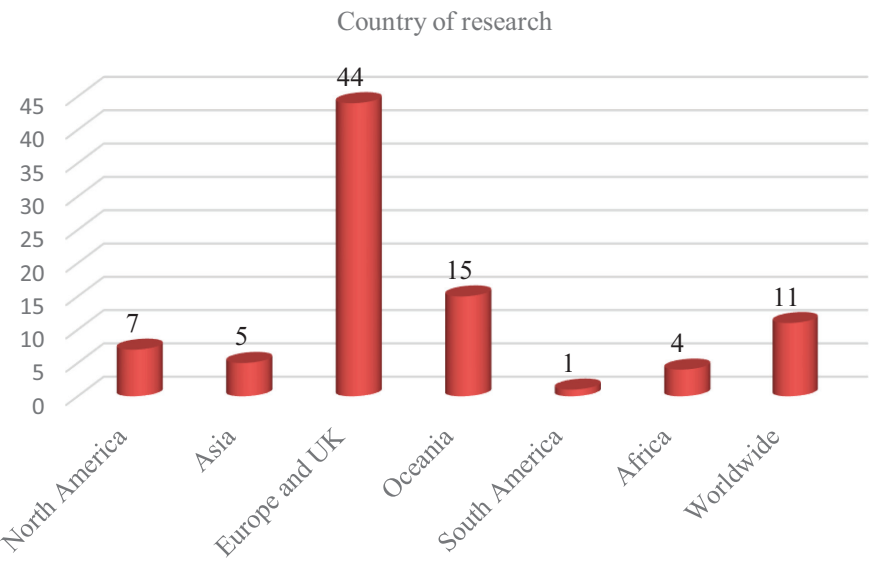




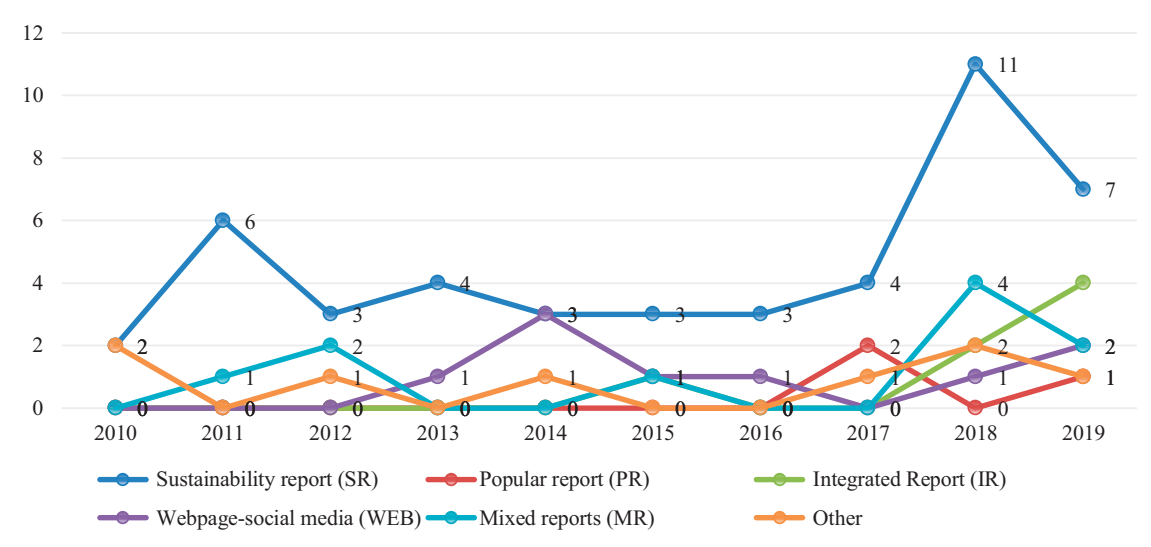

\begin{tabular}{|l|r|r|r|r|r|r|r|r|r|r|r|r|}
\hline $\begin{array}{l}\text { Rep./ } \\
\text { Year }\end{array}$ & 2010 & 2011 & 2012 & 2013 & 2014 & 2015 & 2016 & 2017 & 2018 & 2019 & TOT \\
\hline SR & 2 & 6 & 3 & 4 & 3 & 3 & 3 & 4 & 11 & 7 & 46 \\
\hline PR & 0 & 0 & 0 & 0 & 0 & 0 & 0 & 2 & 0 & 1 & 3 \\
\hline IR & 0 & 0 & 0 & 0 & 0 & 1 & 0 & 0 & 2 & 4 & 7 \\
\hline WEB & 0 & 0 & 0 & 1 & 3 & 1 & 1 & 0 & 1 & 2 & 9 \\
\hline MR & 0 & 1 & 2 & 0 & 0 & 1 & 0 & 0 & 4 & 2 & 10 \\
\hline Other & 2 & 0 & 1 & 0 & 1 & 0 & 0 & 1 & 2 & 1 & 8 \\
\hline Total & 4 & 7 & 6 & 5 & 7 & 6 & 4 & 7 & 20 & 17 & 83 \\
\hline
\end{tabular}

Non-financial reporting formats in

PSOs

651

Figure 4.

Articles distribution per type of reports per year [2010-2019] (nr.)

observed in this literature review: namely, SRs (46), IRs (7), PRs (3), webpages/social media (9), mixed reports (10) and others (8). Eight articles published before 2010 (five in the SR category and three in "others") were not included in the figure in order to preserve its clarity.

Not surprisingly, SRs have obtained the greatest attention over the years, with 46 articles (out of 83) discussing this topic, followed by webpages and IR. The few articles discussing other kind of reports consider strategic plans (Mazzara et al., 2010; Sangiorgi et al., 2017), mission statements (Gigli and Tieghi, 2012; Lopez and Martin, 2018), annual reports (Schaffhauser-Linzatti and Ossmann, 2018) or very specific types of reports (Bae, 2014; Baldwin and Uhlmann, 2010; Che Ku Kassim et al., 2019).

Taking into account the large number of articles discussing SRs, IRs and webpages, a more in-depth discussion of the studies dealing with these tools seems worthwhile.

4.3.1 Sustainability reports. Research on SRs in PSOs has been lagging behind, as the research on sustainability issues developed during the 1990s basically focused on corporations (Ball and Grubnic, 2007). However, since the beginning of the new century, academics have progressively engaged with research on non-financial disclosure-namely, sustainability issues in PSOs.

Some of the selected articles investigated the motivations driving PSOs to adopt SRs, and revealed that different pressures push toward the production of such a report. For example, the need to comply with the requirements of funding agencies has been highlighted (Ball, 2005; Rahaman et al., 2004; Bellringer et al., 2011), and sometimes leads to elusive and restricted disclosure. Law requirements (Samkin, 2012), stakeholders' expectations (Bellringer et al., 2011; Fonseca et al., 2011) or the search for legitimacy (Greco et al., 2012) may also stimulate the adoption of SRs. However, a strong legal culture may impede stakeholders' engagement, thus limiting an effective understanding of SRs (Greco et al., 2015). 
JPBAFM 32,4

652
To better identify the determinants that are critical in explaining current practices, the internal context deserves further investigation (Lodhia and Jacobs, 2013), as organizational changes may play a relevant role in the choice of reporting (Siboni et al., 2013; Goswami and Lodhia, 2014; Zhao and Patten, 2016). Domingues et al. (2017) contend that SRs are mainly prompted by internal motivations, and their adoption can be a driver for organizational changes toward more sustainability-oriented PSOs.

Other determinants positively affecting the diffusion of SRs have been identified in the national context (Romolini et al., 2015) and industry (Garde Sánchez et al., 2017). Contrasting results have been collected for size, which seems to be a positive determinant leading to the preparation of SRs in some studies (Argento et al., 2019b; Garde Sánchez et al., 2017; Giacomini et al., 2018; Sassen et al., 2018) and not related to the adoption of SRs in others (Siboni et al., 2013). In the context of SOEs, profitability and a state representative on the board may also positively affect the disclosure of sustainability issues (Argento et al., 2019b).

Furthermore, in the experiences examined, some integration between economic and sustainability issues has been detected (e.g. Gamage and Sciulli, 2017), and narrative disclosure generally prevails for quantitative or monetary information (Guthrie and Farneti, 2008; Kansal et al., 2018; An et al., 2017). Interestingly enough, SRs have been also used to disclose intellectual capital (Sangiorgi and Siboni, 2017).

Few studies testify to positive societal changes connected to SR initiatives. However, Bergmans et al. (2014) examine the experience of the port of Antwerp (Belgium), where SRs paved the way for community participation and stakeholders' dialogue.

Organizational outcomes emerging from SR adoption, such as increased staff motivation and data management capacities (Niemann and Hoppe, 2018), seem to be strongest in the initial period of SR adoption, while effectiveness is lost once the practice becomes institutionalized (Mussari and Monfardini, 2010). Furthermore, a stand-alone report can often include incomplete or inconsistent information (Farneti et al., 2019b).

The use of guidelines remains jeopardized, and the publication of SRs sometimes seems to be more the consequence of a managerial fashion than the result of profound organizational changes (Ball, 2005; Farneti et al., 2019a; Marcuccio and Steccolini, 2005; Vinnari and Laine, 2013). In any case, this trend has opened the way for the participation of stakeholders in decision-making and has improved the consideration of sustainability aspects in global management planning (Yáñez et al., 2019).

The lack of specific law requirements supporting the preparation of SRs (Greco et al., 2012; Giacomini et al., 2018; Farneti et al., 2019b) emerges once again, as well as the lack of GRI guidelines specific for each kind of organization. These limitations may prevent SRs by having a concrete influence on social (Greiling et al., 2015; Del Sordo et al., 2016) and environmental strategies (Sciulli, 2011). A managerialist approach seems to prevail (Dumay et al., 2010), in addition to a cherry-picking attitude, in the selection of indicators to be disclosed (Guthrie and Farneti, 2008; Fonseca et al., 2011). Furthermore, strict regulation may lead to a "ritualistic use" of SRs (Mussari and Monfardini, 2010). Scholars agree that in the absence of mandatory requirements, self-serving legitimation, community engagement and accountability pressures are the main reasons for SR adoption in PSOs (Bellringer et al., 2011; Sciulli, 2011; Greco et al., 2015; Che Ku Kassim et al., 2019).

4.3.2 Integrated reports. Integrated reporting is a new communication tool that has gained prominent relevance in the last few years, due to its ability to convey financial and nonfinancial information in a single report, which supports investors and other stakeholders in understanding how an organization manages its value-creation process (Argento et al., 2019a; de Villiers et al., 2017; Iacuzzi et al., 2020). Seven articles deal with experiences undertaken by PSOs in adopting IRs, mainly following a case-study method. Five articles undertake in-depth investigation through case studies in healthcare institutions (Cavicchi et al., 2019), SOEs (Farneti et al., 2019a; Montecalvo et al., 2018), HEIs (Veltri and Silvestri, 2015) and central 
government (Caruana and Grech, 2019). These five articles are all motivated by the need to better understand to what extent adopting IRs can improve sustainability disclosure, promote integrated thinking and induce organizational changes.

Some of the articles conclude that IRs may represent an important challenge for PSOs to improve their decision-making process and sustainability reporting, while providing a clearer picture of their value-creation process (Montecalvo et al., 2018). Caruana and Grech (2019) show a positive stance toward the possible adoption of IRs by the Maltese government. Farneti et al. (2019a) and Montecalvo et al. (2018) ascertain that the adoption of IRs has improved sustainability reporting in the New Zealand Post. However, considering the SOE context, Tirado-Valencia et al. (2019, p. 14) discover that "internal processes should be better coordinated and that there is a need of greater involvement of the managers with nonfinancial aspects." Similarly, Cavicchi et al. (2019) reveal that IRs might be perceived as a further burden rather than a support to the decision-making process in the healthcare context, due to the limited capabilities of organizations' institutional shareholders to perceive possible benefits. Veltri and Silvestri (2015) show that the adoption of IRs in a South African HEI mainly stems from institutional pressures, but that the interconnection of capitals is not disclosed, stakeholders' relationships are not highlighted and the level of reliability of the IR seems low. Nonetheless, from a theoretical viewpoint, Adams (2018) theorizes that IRs can support HEIs in better developing their strategies around the value-creation process.

All in all, SRs and, more broadly, the reporting of sustainability issues by PSOs through different formats, undoubtedly dominate the discussion within the articles included in this literature review. As highlighted before, scholars investigating all kinds of PSOs around the world are paying increasing attention to sustainability issues and the variety of disclosure tools adopted. Nonetheless, it must be noted that, although "sustainability is a master concept within contemporary organizations and should be central to public services" (Guthrie et al., 2010, p. 450), it seems that PSOs are still taking hesitant steps into reporting about sustainability, social and environmental strategies and undertaken actions (Lopatta and Jaeschke, 2014; Sepasi et al., 2019). Production of SRs or other non-financial reports-as well as the embracing of organizational changes in order to connect with sustainability strategies and/or more holistic communication-remains scant, requiring stronger efforts by researchers (Fusco and Ricci, 2019).

4.3.3 Webpages/social media. PSOs, mimicking the common practice of corporations and for-profit organizations, are increasingly making use of webpages and social media to reach a wider plethora of stakeholders with fewer costs and timelier disclosure (Manes-Rossi et al., 2018). Research is taking its first steps in this field, as only nine articles (out of 91) deal with this innovative communication tool. These articles show a growing trend of PSOs using webpages to disclose information related to social, environmental and sustainability issues. All of the articles are based on content analysis, although Navarro-Galera et al. (2016) use the results emerging from this analysis as a base for a cluster analysis to identify factors that might promote a wider disclosure of sustainability information on the webpages of Spanish regional governments.

It is also worth noticing that eight articles examine regional or local government, while only one investigates HEI webpages. Three articles come from the same research team (Alcaraz-Quiles et al., 2014, 2015; Ortiz-Rodríguez et al., 2018) and focus on web disclosure provided by European local and regional governments. The team's research provides evidence of the importance of cultural and social factors in online sustainability disclosure. Their results are also in line with those from Navarro-Galera et al. (2014) and Ruiz-Lozano et al. (2019). These last two articles show that, compared with their peers in Nordic countries, Anglo-Saxon LGs make greater use of their webpages as an instrument of transparency for sustainability information, which demonstrates the importance of social and cultural context.
Non-financial reporting formats in PSOs

653 
JPBAFM 32,4

\section{4}

Furthermore, Joseph et al. (2014) report that Local Agenda 21 and public sector awards are good predictors of online sustainability disclosure.

Even though research on online sustainability and social and environmental disclosure by PSOs is in its infancy, it is evident that the increasing use of webpages as a tool for PSOs to engage with their stakeholders will attract growing attention from scholars in the near future.

\subsection{Focus of literature}

Examining the results of the fourth category, "focus of literature", makes it possible to identify the most researched areas of interest. This reveals where researchers focus the most attention and which areas remain under-investigated and identifies gaps that deserve further attention (Bisogno et al., 2018).

Figure 5 displays a decisive prevalence of articles dealing with external reporting (57 out of 91; i.e. $63 \%$ ) and a total lack of attention for auditing and assurance issues ( 0 articles). This is not surprising, as growing concerns about the social, economic and environmental impacts of public sector activities have increased the pressure on PSOs to be accountable toward stakeholders and to improve their non-financial disclosure (Dumay et al., 2010; Farneti and Siboni, 2011; Domingues et al., 2017). Therefore, scholars are addressing PSOs' nonfinancial reporting practices due to stakeholders' dissatisfaction with traditional financial reporting. The shortage of non-financial information has been recognized in the literature (Merchant and Van der Stede, 2007) and PSOs are not exempt from such limitations.

As was highlighted in Subsection 4.3, a strong proclivity toward analysis of the level of disclosure provided by different types of PSOs (prevalently HEIs and LGs) through SRs emerges. Yet, in recent years, scholars have begun to explore innovative reporting tools such as webpages (e.g. Alcaraz-Quiles et al., 2014, 2015; Ortiz-Rodríguez et al., 2018; Ruiz-Lozano et al., 2019), IRs (e.g. Veltri and Silvestri, 2015; Farneti et al., 2019a; Tirado-Valencia et al., 2019) and PRs (e.g. Manes-Rossi et al., 2020).

Figure 5 shows that 24 articles $(26 \%)$ concentrate on accountability and governance. This result indicates that some scholars have attempted to gain insights from the social and organizational context, governance mechanisms and the managerial processes underpinning reporting practices. According to Niemann and Hoppe (2018), a high level of disclosure does not necessary correspond to high levels of transparency and accountability. Thus, further critical and alternative research is necessary.

Furthermore, it is worth noting that seven articles out of $91(8 \%)$ explore non-financial reporting formats from a management control/strategy perspective, investigating the organizational practices and actors involved in PSOs' environmental reporting practices (e.g.

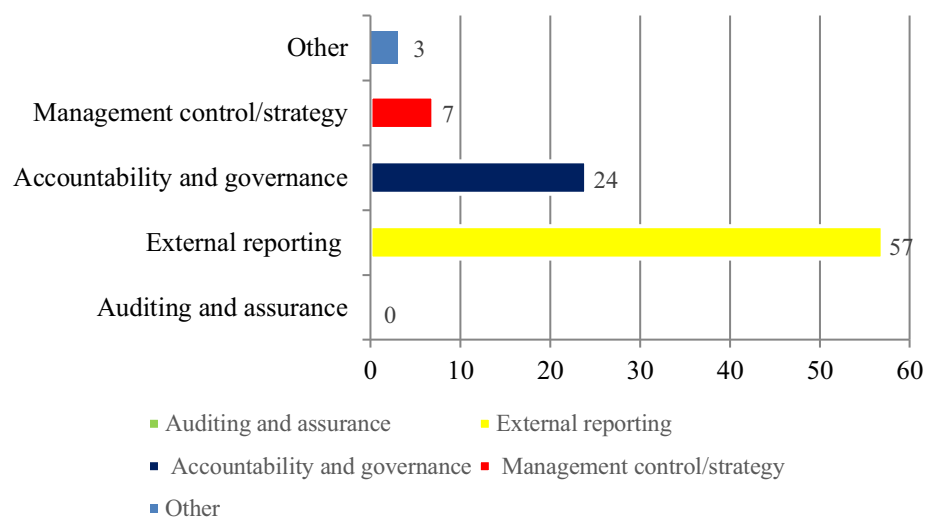

Figure 5.

Articles distribution per focus of literature (nr.) 
Ball, 2005; Lodhia and Jacobs, 2013) or identifying the main links between SR adoption and organizational change management in PSOs (e.g. Domingues et al., 2017). Lastly, only three articles $(3 \%)$ follow other research paths, such as a literature review on social and environmental accounting in PSOs (Fusco and Ricci, 2019).
Non-financial reporting formats in

PSOs

\subsection{Methods adopted}

Figure 6 illustrates the results related to the fifth category: the "research methods" adopted in the 91 reviewed articles. It shows how scholars have gathered insights into non-financial reporting formats in PSOs and how research is evolving between theoretical and empirical paths.

As Figure 6 shows, the sub-category "literature review" is the least addressed, as it is only represented by the article by Fusco and Ricci (2019), which is a bibliometric analysis exploring social and environmental accounting research paths in the public sector. This analysis outlines a strong tendency toward empirical rather than conceptual research approaches. Scholars prefer content/historical analysis (40 articles; i.e. $44 \%$ ) and case and field studies (25 articles; i.e. $27 \%$ ) to other methods (i.e. commentary/policy/normative methods). Research in this field is progressing into a mature stage in which scholars are gathering insights into how PSOs actually disclose non-financial information through nonfinancial reporting formats and are drawing practical implications about the organizational and governance processes underpinning reporting practices.

Content analysis has a long history in both financial and non-financial accounting studies (e.g. Hackston and Milne, 1996; Guthrie et al., 2006; de Villiers and Van Staden, 2011). The majority of the sampled articles use this approach to assess the level of social and environmental disclosure provided by different types of PSOs through SRs (e.g. Guthrie and Farneti, 2008; Greiling et al., 2015; Argento et al., 2019b), with a strong focus on HEIs (e.g. Fonseca et al., 2011; Lopatta and Jaeschke, 2014; Gamage and Sciulli, 2017; Sepasi et al., 2019). However, content analysis has also been used to examine other non-financial reporting formats, such as webpages (e.g. Frias-Aceituno et al., 2013; Alcaraz-Quiles et al., 2014, 2015; Ruiz-Lozano et al., 2019), PRs (e.g. Jordan et al., 2017; Manes-Rossi et al., 2020), IRs (e.g. TiradoValencia et al., 2019), strategic plans (e.g. Mazzara et al., 2010; Sangiorgi et al., 2017) and HEIs' mission statements (e.g. Lopez and Martin, 2018).

Many of the articles employ content analysis to generate data that is subsequently used to perform statistical analysis (e.g. mean tests; linear and panel regression models). In most cases, potential factors related to economic, demographic, social, financial, governance and

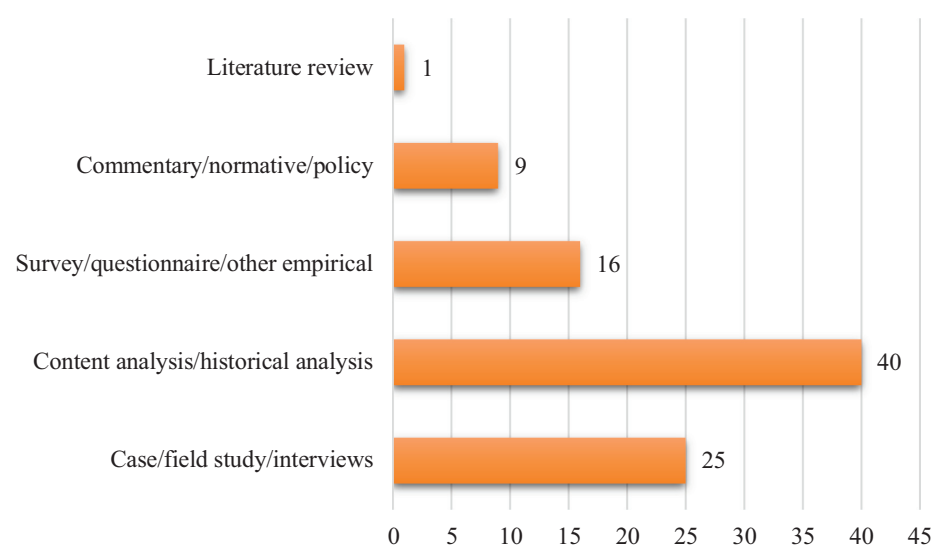

Figure 6.

Articles distribution per research methods (nr.) 
JPBAFM 32,4

cultural aspects are tested as potential determinants of the level of disclosure provided through the non-financial reporting formats examined (e.g. Frias-Aceituno et al., 2013; Alcaraz-Quiles et al., 2014, 2015; Argento et al., 2019b; Farneti et al., 2019b).

Following a similar pattern, case studies have been widely adopted in accounting research (Merchant and Van der Stede, 2007; Bisogno et al., 2018) to conduct deep and holistic analyses of complex phenomena in circumscribed social, economic and organizational contexts (Scapens, 1990; Yin, 2014). Most case studies in this field focus on SRs (e.g. Madeira et al., 2011; Monfardini et al., 2013; Goswami and Lodhia, 2014; Niemann and Hoppe, 2018). Nonetheless, a growing number of exploratory articles dealing with the IR have been published (e.g. Veltri and Silvestri, 2015; Montecalvo et al., 2018; Caruana and Grech, 2019; Cavicchi et al., 2019; Farneti et al., 2019a). This result sheds light on the relevance of the IR as an emerging reporting trend in the public sector. A case study may be a suitable method to obtain insights into the challenges arising from IR adoption in different types of PSOs and the possible benefits, given the IR's potential to both stimulate internal changes and promote accountability and transparency (Tirado-Valencia et al., 2019).

Stemming from the shortcomings of PSOs' sustainability disclosure, which have been ascertained by many articles, $18 \%$ of the analyzed articles (i.e. 16 out of 91 ) involved surveys and questionnaires to explain the reasons driving the adoption of the SR and the barriers that limit its diffusion in PSOs (e.g. Williams et al., 2011; Domingues et al., 2017; Giacomini et al., 2018). Lastly, it is worth noting that nine articles (10\% of the sample) follow a commentary/ normative approach and can thus be defined as "conceptual" studies (Bracci et al., 2019, p. 112). These articles are mainly theoretical, as they offer discussions and debates that are not supported by empirical evidence. However, theoretical articles provide a valuable contribution - especially in the case of emerging research fields, such as the adoption of innovative reporting formats (i.e. IRs and PRs) in PSOs - in enriching the debate about accountability innovations in the public sector and depicting future research paths for scholars (e.g. Cohen and Karatzimas, 2015; Adams, 2018; Biondi and Bracci, 2018; ManesRossi, 2019).

\subsection{Reporting frameworks and models}

The sixth category, "frameworks and models," focuses on the reporting framework and models adopted in the reviewed articles. The number of frameworks discussed in the literature is a good proxy for understanding the maturity or novelty of a given research topic (Guthrie et al., 2012; Massaro et al., 2016; Bracci et al., 2019).

Figure 7 shows that almost half of the articles (i.e. 44 articles or $48 \%$ ) apply or consider previously reported frameworks/models (i.e. the GRI, IRF). This result indicates a fair degree of continuity among the studies conducted on this topic (Bracci et al., 2019) and shows the willingness of scholars to use well-established frameworks in order to ensure the objectivity, reliability and comparability of results (Lopatta and Jaeschke, 2014; Sassen and Azizi, 2018; Ruiz-Lozano et al., 2019). The most-adopted reporting frameworks for investigating nonfinancial information are the different versions of the GRI guidelines and standards, and the framework released by the International Integrated Reporting Council (IIRC).

The GRI was created with the main aim of stimulating the standardization of sustainability reporting worldwide and providing a framework for organizations interested in conveying all three aspects of performance (economic, social and environmental) to stakeholders. By the time the second version of the SR framework was released in 2002, the GRI guidelines were already the most widely adopted reporting framework (Szejnwald Brown et al., 2009). The last version of the GRI guidelines (G4) was superseded in 2016 by the GRI Standards, which have a modular and interrelated structure (https://www.globalreporting.org/). 

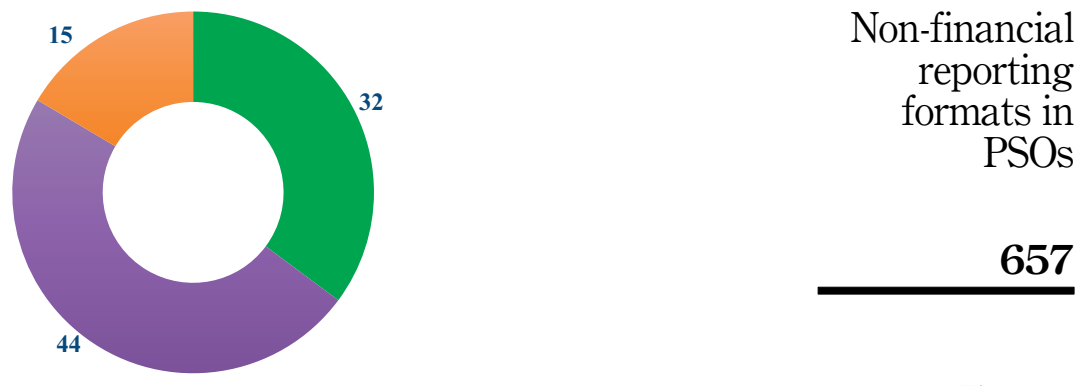

- No model proposed

- Applies or considers previous models/framework

a Proposes a new model

Figure 7.

Articles distribution per reporting framework/model used (nr.)

The IIRC Framework was issued by the IIRC in 2013 with the aim of supporting organizations in disclosing how they create value, by looking at the governance, strategies and past and future performance in relation to six capitals: financial, manufactured, intellectual, human, social and relationship and natural (https://integratedreporting.org/). The interrelation among capitals and integrated thinking constitute the basic ideas on which information must be developed. To this end, the IIRC Framework provides guiding principles and content elements to be included in IRs. However, no indicators are provided and reference to other guidelines and frameworks is also possible, which encourages organizations to use GRI indicators while developing IRs (Liu et al., 2019).

Despite criticism related to an excessively generic approach to reporting (Guthrie and Farneti, 2008; Lodhia et al., 2012; Larrinaga et al., 2018) and a lack of indicators addressing the specificities of different types of PSOs, such as HEIs (Lopatta and Jaeschke, 2014; Bice and Coates, 2016; Gamage and Sciulli, 2017), the GRI guidelines (G3 and G4) and related public sector supplements (GRI, 2005, 2010) remain the main framework used by scholars to examine sustainability disclosure (e.g. Alcaraz-Quiles et al., 2014, 2015; Greiling et al., 2015; Sassen and Azizi, 2018). Concerning research on IRs, three articles use the framework released in 2013 by the IIRC. Veltri and Silvestri (2015) and Caruana and Grech (2019) refer to the entire IR framework, including capitals, guiding principles and content elements, to respectively examine the IR practice of a South African public university and the gap between the current annual reporting practices of a Maltese government and the IR framework. In contrast, Farneti et al. (2019a) focus only on the three IR social capital categories (intellectual capital, human capital and social and relationship capital) to examine the social disclosures provided by a New Zealand SOE through IRs.

A significant number of the sampled articles (i.e. 32 articles, 35\%) do not propose a model. These articles propose context-specific case studies (e.g. Ball, 2005; Marcuccio and Steccolini, 2005; Greco et al., 2015) or conduct surveys and questionnaires (e.g. Williams et al., 2011; Zhao and Patten, 2016; Domingues et al., 2017; Giacomini et al., 2018) and draw upon various theories. Other articles offer conceptual debates (e.g. Adams, 2018; Manes-Rossi, 2019) that do not require the development or use of a specific framework of analysis.

It is notable that 15 articles $(17 \%)$ introduce new models when inquiring into emerging reporting trends such as PRs (e.g. Cohen and Karatzimas, 2015; Cohen et al., 2017; Jordan et al., 2017; Manes-Rossi et al., 2020) and IRs (e.g. Tirado-Valencia et al., 2019). This underlines the novelty of a research field in which the development of new insights requires the creation of 
JPBAFM 32,4

new reporting frameworks and models to investigate non-financial reporting formats (Bisogno et al., 2018; Bracci et al., 2019). However, the development of new reporting frameworks and models can also represent an attempt to overcome the limitations of traditional models. This is the case for some studies inquiring into SRs, which collect data and pick up indicators from different established frameworks (e.g. GRI guidelines) to develop new models that are more suitable for investigating a specific context, report or type of PSO (e.g. Fonseca et al., 2011; Madeira et al., 2011).

\subsection{Academics and practitioners}

In order to determine to what extent the literature on non-financial reporting format incorporates the voice of practitioners and consultants - whether jointly with academics or alone-the analytical framework included the seventh category, "academics and practitioners." This category is justified by the debate among academics and practitioners about public sector accounting and accountability, which shows that academic research does not always influence accounting practices (Steccolini, 2019).

Data collected in this SLR reinforces this belief, as only $10 \%$ of the analyzed articles were written by a team that included at least one practitioner (e.g. Baldwin and Uhlmann, 2010; Cotterell and Crothers, 2011; Caruana and Grech, 2019). The remaining articles (90\%) were authored by academics. None of the selected articles were written by practitioners alone.

\section{Non-financial reporting formats: a critical summary and future research agenda}

Considering the results presented above, it can be concluded that research on non-financial reporting formats in PSOs is an emerging field of research. The number of published articles has increased over the last three years, and interesting results have contributed to our understanding of the reporting formats used in the public sector. This critical analysis of the existing literature makes it possible to raise some remarks on its strengths and on potential areas to be further developed.

First, the majority of the examined articles focus on sustainability reporting, which reflects an increased awareness that the disclosure of financial information is insufficient to satisfy the current information needs of stakeholders (Adams, 2018). On the one hand, stakeholders have been considered a key element in the development of non-financial reporting formats (Alcaraz-Quiles et al., 2015). Nevertheless, additional research is needed to better understand how the value and interests of both internal and external stakeholders (Lodhia et al., 2012) influence non-financial reporting in the public sector. Future research could investigate how PSOs ensure that the stakeholder representatives engaged in the reporting process defend the general interest and not their own (Ferrero-Ferrero et al., 2018).

On the other hand, it has been contested that stakeholders may not understand the content of the SRs prepared by PSOs, which calls into question PSOs' efforts to educate the public on sustainability matters (Greco et al., 2015). Although PSOs use non-financial reporting formats, their choice might be the result of trends, rather than of an understanding of the actual information needs of their stakeholders (see Biondi and Bracci, 2018). Scholars could devote special attention to the information needs of one specific category of stakeholdersnamely, citizens (Manes-Rossi et al., 2020; Jordan et al., 2017) - and their reactions in terms of their understanding of the information disclosed (Manes-Rossi, 2019).

Future studies could concentrate on the usefulness and impact of the information disclosed by PSOs (Niemann and Hoppe, 2018). Both aspects relate to the readability of nonfinancial reporting formats and to the capacity of stakeholders to interpret the information provided in various types of reports. In this respect, the literature has emphasized that the integration of various non-financial reports would avoid redundancy and facilitate the 
comparability of the information disclosed by PSOs (Del Bello, 2006). Therefore, further research could dig deeper into how such reports are designed and implemented by focusing on their diffusion and on stories of success and failure (Biondi and Bracci, 2018). The relationships between various reporting formats (Fusco and Ricci, 2019) and the overlaps or inconsistencies among publicly available information should be explored in future research.

Second, many studies have provided insights into the determinants of sustainability reporting (e.g. Sassen et al., 2018; Siboni et al., 2013) without yielding unanimous results. Concerning HEIs, there is an explicit plea for more comparative studies between HEIs in different geographical and political contexts (e.g. Bice and Coates, 2016; Lopatta and Jaeschke, 2014). In addition to considering geographical and political factors, ownership could be investigated by comparing the sustainability reporting trends of public and private HEIs (Zorio-Grima et al., 2018).

When focusing on factors explaining LGs' non-financial disclosure, size and time/ availability of staff might be determinants in the preparation of SRs (Giacomini et al., 2018). The cultural context may also influence the transparency of the sustainability practices of LGs (Ruiz-Lozano et al., 2019) and could be investigated further in future studies.

A similar trend can be seen in relation to SOEs. The most commonly examined factors affecting non-financial disclosure include size, extent of public ownership, profitability and industry (e.g. Argento et al., 2019b; Larrinaga-Gonzélez and Pérez-Chamorro, 2008; Andrades Peña and Larrán Jorge, 2019). However, the results are not always unanimous and, following the advice of Garde Sánchez et al. (2017), future studies could consider other variables in order to achieve a better understanding of the factors explaining SOEs' disclosures. Inspired by the findings of Zhao and Patten (2016), who claim that the dominant source of pressure for social and environmental reporting derives from peer institutions, future research could also dig deeper into the disclosure practices of SOEs operating in special industries such as gambling, the pharmaceutical industry and alcohol (Argento et al., 2019b; Andrades Peña and Larrán Jorge, 2019).

Hence, additional research on the reasons/motivators/drivers of non-financial reporting formats by PSOs is welcome (see Hossain, 2018; Marcuccio and Steccolini, 2005). Comparative studies may be beneficial (Mazzara et al., 2010), and more factors explaining the varying scope and focus of non-financial reporting formats, such as cultural differences (OrtizRodríguez et al., 2018) and country peculiarities, may be considered.

Third, in relation to the disclosure of the three dimensions of sustainability (economic, environmental and social), the reviewed articles present inconclusive results. Some studies found that the social dimension is prioritized (Williams et al., 2011), while others concluded that it is the least developed (Greiling et al., 2015; Lopatta and Jaeschke, 2014; Lozano, 2011). Some scholars observed an excessive focus on environmental reporting (An et al., 2017; Gamage and Sciulli, 2017; Sassen and Azizi, 2018), while others concluded that environmental information is less disclosed than economic and social information (Frias-Acetuno et al., 2013; Alcaraz-Quiles et al., 2014).

These inconsistencies explain calls for the development of reporting frameworks that are replicable in order to ensure comparability and fair benchmarking (Fonseca et al., 2011; Huber and Bassen, 2018; Schaffhauser-Linzatti and Ossmann, 2018). A unified reporting method could be beneficial for both the preparers (i.e. saving of cost, time and human resources) and the readers (Sassen and Azizi, 2018). However, the question of the appropriateness of using the GRI framework when preparing SRs remains, given that scholars have raised doubts regarding that framework even though it is widely used (Baldwin and Uhlman, 2010; Del Sordo et al., 2016; Dumay et al., 2010).

A challenge for future research is to find new directions in non-financial reporting formats, given that the reliance on private sector reporting models does not lead to optimal results (Larrinaga et al., 2018). In sum, researchers may contribute to the development of appropriate
Non-financial reporting formats in

PSOs

659 
JPBAFM 32,4

660 reporting frameworks (Sepasi et al., 2019), thereby lending relevance and usefulness to the reports, because the GRI supplement for the public sector does not fulfill its reporting duties.

Considering the indicators that are disclosed in SRs, the literature has identified some concerns regarding the number and type of indicators selected by preparers (Guthrie and Farneti, 2008; Goswami and Lodhia, 2014). The number of indicators matters depending on whether they are used for external reporting or internal management reasons (Maderia et al., 2011). Type of indicator is relevant for comparability purposes (Fonseca et al., 2011; Cotterell and Crothers, 2011). These reflections show a lack of knowledge on the connections between non-financial reporting practices and management control systems. Additional research could investigate how PSOs set sustainability-related goals and targets, and monitor their implementation (Madeira et al., 2011; Calitz et al., 2018; Kräusche and Pilz, 2018) by focusing on data generating and analysis methodologies.

Fourth, after reading the articles by Greiling et al. (2015), Alcaraz-Quiles et al. (2015) and Romolini et al. (2015), it becomes clear that research on internal management information systems and processes related to the preparation of non-financial reports is needed. Focusing on intra-organizational aspects and governance mechanisms is relevant because poorly designed data-collection processes and a lack of support from managers and leaders can negatively influence PSOs' orientation toward sustainability (Domingues et al., 2017). When data is spread across and between different governmental levels, it becomes costly to collect the information needed to prepare SRs (see Alcaraz-Quiles et al., 2015; Sciulli, 2011). These issues call for additional investigations of internal and external coordination efforts.

Future studies could shift the focus from the individuals who actively engage in nonfinancial reporting to other organizational actors (Del Sordo et al., 2016). For example, Alcaraz-Quiles et al. (2014) suggest that conducting "awareness-raising meetings" with heads of departments and officials can raise their interest and engagement in the coordinated preparation of SRs in LGs. Dialogues can lead to important results that go beyond new reporting practices to create a sense of community identity (Bergmans et al., 2014). Therefore, research on the degree of internalization of sustainability reporting and capacity building within PSOs (Yáñez et al., 2019; Gigli and Tieghi, 2012; Greco et al., 2012; Sciulli, 2011) can add value to the literature on non-financial reporting formats in the public sector. It could also be interesting and relevant to investigate the extent to which managers and politicians use nonfinancial reports for decision-making.

Fifth, some reflections can be raised concerning the debate on voluntary versus mandatory disclosure of sustainability-related information (Bae, 2014; Guthrie and Farneti, 2008; Seibert and Macagnan, 2019). On the one hand, publishing SRs could be a source of legitimacy for PSOs (Brusca et al., 2018; Che Ku Kissam et al., 2019; Del Sordo et al., 2016; Monfardini et al., 2013). The wish to gain or maintain legitimacy may explain why PSOs voluntarily disclose SRs. On the other hand, the coercive influence of mandatory legislation may be a better explanation for sustainability reporting than legitimacy (Lodhia et al., 2012). Imposing sustainability reporting practices may stimulate ritualistic behaviors in response to strict regulation, rather than generating useful reporting practices (Mussari and Monfardini, 2010).

This discussion can be linked to the contested quality of the SRs prepared by PSOs (e.g. Sepasi et al., 2019; Uyar et al., 2019). Therefore, the real reasons for producing non-financial reporting formats can be scrutinized further, to investigate whether they are being used to "educate and inform" readers or to "change/manipulate" their perspectives (see Frost and Seamer, 2002). Studying why and how PSOs voluntarily disclose information or comply with normative requirements may also clarify the reasons for similarities and differences across countries. An interesting finding of this study is the absence of studies about the auditing and assurance of non-financial reports prepared by PSOs. Future studies could unveil current practices in this respect. 
Sixth, the importance of understanding how PSOs stimulate open dialogues with stakeholders shifts the discussion to the media used by PSOs to communicate with them. Citizens may prefer the webpage format of non-financial reports (e.g. PRs) prepared by LGs, over the pdf format or flipping book format (Cohen et al., 2017). The easy access and functionality of the web can facilitate reaching more citizens (Navarro-Galera et al., 2016). It follows that future research could focus on the use of new technologies to disclose information to citizens in a user-friendly, dynamic and understandable way.

For the future development of non-financial reporting practices, it would be beneficial to uncover PSOs' motivations for why they report and how they plan their actual disclosures on webpages (Hossain, 2018). Given that most of the existing literature has focused on the webpage disclosures of local and regional governments, it would be interesting to expand such investigations to other types of PSOs as well, including HEIs (see also Lopez and Martin, 2018).

Seventh, this study reveals that articles about integrated reporting in PSOs are still scant. Interesting insights for further research can be obtained. Despite the potential of IRs to disclose more information on value-creation processes (Argento et al., 2019a; Iacuzzi et al., 2020; Kansal et al., 2018), actual practice may reveal difficulties in providing relevant information in a concise, consistent and comparable format (Veltri and Silvestri, 2015). Given this criticality, it seems reasonable to follow the suggestion of Cohen and Karatzimas (2015), who promote studies leading to the identification of a template that makes it possible to balance completeness of information with selectiveness. Further studies could also investigate whether IRs enable the reporting of all aspects of sustainability, such as intergenerational equity (Montecalvo et al., 2018).

Through materiality assessment exercises, integrated reporting can lead an SOE to reduce the quantity of social disclosures while making such disclosures more relevant to stakeholders (Farneti et al., 2019a). This result gives hope; further research could dig deeper into materiality (Tirado-Valencia et al., 2019; Lubinger et al., 2019) by, for example, considering the views of different stakeholders in relation to materiality assessment.

The literature on integrated reporting often recalls the concept of integrated thinking (see also Caruana and Grech, 2019). An effective IR requires the collaboration of various organizational functions. Unfortunately, a silo mentality (Cavicchi et al., 2019) is detrimental to integrated thinking. Therefore, future research could examine how PSOs work across boundaries to reach an integrated thinking culture.

Eighth, concerning empirical methods, the majority of the reviewed articles used content analysis and case studies. However, conducting content analysis and statistical tests only allows scholars to analyze the information that PSOs publicly share (Gamage and Sciulli, 2017). Surveys and in-depth interviews with the preparers and readers of non-financial reporting formats might be valuable (see also Sangiorgi and Siboni, 2017; Marcuccio and Steccolini, 2009; An et al., 2017) to capture their perceptions and priorities. Yet a critical approach must be followed, considering that preparers may provide "politically correct" answers to legitimate their reporting activity (Bellringer et al., 2011). To overcome such risks, further research could be longitudinal (Joseph et al., 2014) and extend over longer periods of time (Vinnari and Laine, 2013) so as to explore the role of non-financial reporting in different organizations and contexts.

In addition, content analysis has commonly been adopted to investigate the determinants of online disclosure. Future research could prepare case studies exploring why and how PSO managers decide to disclose certain information on the web. Studies about IRs are mostly conducted with the case study method. Further studies could also adopt other research methods to grasp the similarities and differences of PSOs' IRs around the world.

Ninth, given the important role that practitioners and accountants can play in driving sustainable development (Ball, 2005; Manes-Rossi et al., 2020), governments, HEIs and
Non-financial reporting formats in

PSOs 
JPBAFM 32,4

662

professional accounting bodies could be more active in equipping future accountants with knowledge and skills related to non-financial reporting formats. This call paves the way for additional future research that includes reflections and perspectives from consultants and civil servants.

Considering these reflections, some final and overarching remarks are presented in the concluding section.

\section{Concluding remarks}

In addressing the recent call by Kaur and Lodhia (2019), and considering the increasing accountability pressure experienced by PSOs (Almqvist et al., 2013), this paper has revealed the state of the art and areas for future research on non-financial reporting formats in the public sector. Two research questions have guided the study. The first question aimed to highlight the trends and recurring themes of the existing literature on non-financial reporting formats in the public sector. The second question aimed to identify the main gaps in the current research on non-financial reporting formats in PSOs.

To answer those questions, an SLR, inspired by Guthrie et al. (2012), Dumay et al. (2015; 2016), and Bisogno et al. (2018), was executed by analyzing 91 articles. This paper revealed that most studies focus on the sustainability reporting of LGs and HEIs, followed by SOEs, in Europe/UK and Oceania. The findings on the type of PSOs show that research on the healthcare sector (e.g. Monfardini et al., 2013; Cavicchi et al., 2019) and on central and regional governments is still scant. We call on scholars to devote their research efforts to understanding these types of organizations' practices in relation to non-financial reporting formats. This call may also extend to the growing interest of accounting scholars in smart cities, a type of PSO that crosses traditional boundaries and has a holistic approach to public services (see Argento et al., 2020).

In relation to the countries that have been studied in the existing literature, while Europe, the UK and Oceania are somewhat well explored, more knowledge of how non-financial reporting formats are evolving in other parts of the world, such as Africa, Asia and South America, would be desirable. In addition, the findings reveal that most studies have investigated the drivers of sustainability reporting and online disclosure. Although research on the use of webpages is gaining importance, more efforts on integrated and popular reporting would be welcome.

We ask for additional studies on internal change processes and governance mechanisms, as well as auditing and assurance practices, which promote theoretical and methodological eclecticism. The literature frequently refers to the need for PSOs to be legitimate. This focus on legitimacy may explain why legitimacy theory has proven to be a beneficial theoretical lens (Seibert and Macagnan, 2019). Yet alternative theoretical lenses, which go beyond the well-known institutional, stakeholder and agency theory, might also be used when conducting further studies. To achieve a deeper understanding of actual alternative nonfinancial reporting practices, involving practitioners in academic work (or the other way around) would also be beneficial.

This paper is not only relevant for academics who wish to engage in research on nonfinancial reporting formats. By suggesting further research on the reasons for the success and failure of non-financial reporting initiatives, this paper is useful to policymakers who may rethink their roles as facilitators of sustainability initiatives and increased dialogue with citizens. Even preparers of PSOs' non-financial reporting formats can benefit from reading this paper.

Like any other study, this work is not free from limitations. Despite the structured approach that was followed to conduct the literature review and the additional search for relevant articles, some contributions focusing on PSOs may be missing. The criteria that were 
established for the search, selection and analysis of the articles may have influenced the results. In conclusion, some questions still remain open. Why have some parts of the world received less attention? Is it difficult to obtain sensitive information on internal preparation processes? What alternative empirical methods and theories can be adopted? These and other questions can motivate scholars to conduct further research.

\section{References}

The articles marked with * are included in the structured literature review.

* Adams, C.A. (2018), "Integrated reporting and accounting for sustainable development across generations by universities", Public Money and Management, Vol. 38 No. 5, pp. 332-334.

* Alcaraz-Quiles, F.J., Navarro-Galera, A. and Ortiz-Rodríguez, D. (2014), "A comparative analysis of transparency in sustainability reporting by local and regional governments", Lex Localis Journal of Self-Government, Vol. 12 No. 1, pp. 55-79.

* Alcaraz-Quiles, F.J., Navarro-Galera, A. and Ortiz-Rodríguez, D. (2015), "Factors determining online sustainability reporting by local governments", International Review of Administrative Sciences, Vol. 81 No. 1, pp. 79-109.

Almqvist, R., Grossi, G., van Helden, G.J. and Reichard, C. (2013), "Public sector governance and accountability", Critical Perspectives on Accounting, Vol. 24 Nos 7-8, pp. 479-487.

* An, Y., Davey, H. and Harun, H. (2017), "Sustainability reporting at a New Zealand public university: a longitudinal analysis", Sustainability, Vol. 9 No. 9, pp. 1-11.

* Andrades Peña, J. and Larrán Jorge, M. (2019), "Examining the amount of mandatory non-financial information disclosed by Spanish state-owned enterprises and its potential influential variables", Meditari Accountancy Research, Vol. 27 No. 4, pp. 534-555.

Argento, D., Culasso, F. and Truant, E. (2019a), "From sustainability to integrated reporting: the legitimizing role of the CSR manager", Organization and Environment, Vol. 32 No. 4, pp. 484-507.

* Argento, D., Grossi, G., Persson, K. and Vingren, T. (2019b), "Explaining sustainability disclosures of hybrid organizations: the case of Swedish state-owned enterprises", Meditari Accountancy Research, Vol. 27 No. 4, pp. 505-533.

Argento, D., Grossi, G., Jääskeläinen, A., Servalli, S. and Suomala, P. (2020), "Governmentality and performance for the smart city", Accounting, Auditing and Accountability Journal, Vol. 33 No. 1, pp. 204-232.

* Bae, H. (2014), "Voluntary disclosure of environmental performance: do publicly and privately owned organizations face different incentives/disincentives?", The American Review of Public Administration, Vol. 44 No. 4, pp. 459-476.

* Baldwin, C. and Uhlmann, V. (2010), "Accountability in planning for sustainable water supplies in South East Queensland", Australian Planner, Vol. 47 No. 3, pp. 191-202.

* Ball, A. (2005), "Environmental accounting and change in UK local government", Accounting, Auditing and Accountability Journal, Vol. 18 No. 3, pp. 346-373.

* Ball, A. and Grubnic, S. (2007), "Sustainability accounting and accountability in the public sector", in Unerman, J., Bebbington, J. and O’Dwyer, B. (Eds), Sustainability Accounting and Accountability, Routledge, London, pp. 262-284.

* Bellringer, A., Ball, A. and Craig, R. (2011), "Reasons for sustainability reporting by New Zealand local governments", Sustainability Accounting, Management and Policy Journal, Vol. 2 No. 1, pp. 126-138.

* Bergmans, A., Vandermoere, F. and Loots, I. (2014), "Co-producing sustainability indicators for the Port of Antwerp: how sustainability reporting creates new discursive spaces for concern and mobilisation", Journal of Communication Studies, Vol. 7 No. 1, pp. 107-123.
Non-financial reporting formats in

PSOs 
JPBAFM 32,4

664

* Bice, S. and Coates, H. (2016), "University sustainability reporting: taking stock of transparency", Tertiary Education and Management, Vol. 22 No. 1, pp. 1-18.

* Biondi, L. and Bracci, E. (2018), "Sustainability, popular and integrated reporting in the public sector: a fad and fashion perspective”, Sustainability, Vol. 10 No. 9, pp. 1-16, 3112.

Bisogno, M., Dumay, J., Manes Rossi, F. and Tartaglia Polcini, P. (2018), "Identifying future directions for IC research in education: a literature review", Journal of Intellectual Capital, Vol. 19 No. 1, pp. 10-33.

* Bracci, E., Papi, L., Bigoni, M., Gagliardo, E.D. and Bruns, H.J. (2019), "Public value and public sector accounting research: a structured literature review", Journal of Public Budgeting, Accounting and Financial Management, Vol. 31 No. 1, pp. 103-136.

Britten, N., Campbell, R., Pope, C., Donovan, J., Morgan, M. and Pill, R. (2002), "Using meta ethnography to synthesise qualitative research: a worked example", Journal of Health Services Research and Policy, Vol. 7 No. 4, pp. 209-215.

* Brusca, I., Labrador, M. and Larran, M. (2018), "The challenge of sustainability and integrated reporting at universities: a case study", Journal of Cleaner Production, Vol. 188, pp. 347-354.

* Calitz, A., Bosire, S. and Cullen, M. (2018), "The role of business intelligence in sustainability reporting for South African higher education institutions", International Journal of Sustainability in Higher Education, Vol. 19 No. 7, pp. 1185-1203.

* Caruana, J. and Grech, I. (2019), "Tweaking public sector reporting with integrated reporting (IR) concepts", Public Money and Management, Vol. 39 No. 6, pp. 409-417.

* Cavicchi, C., Oppi, C. and Vagnoni, E. (2019), "On the feasibility of integrated reporting in healthcare: a context analysis starting from a management commentary", Journal of Management and Governance, Vol. 23 No. 2, pp. 345-371.

* Che Ku Kassim, C., Ahmad, S., Mohd Nasir, N., Wan Mohd Nori, W. and Mod Arifin, N. (2019), "Environmental reporting by the Malaysian local governments", Meditari Accountancy Research, Vol. 27 No. 4, pp. 633-651.

* Cohen, S. and Karatzimas, S. (2015), "Tracing the future of reporting in the public sector: introducing integrated popular reporting", International Journal of Public Sector Management, Vol. 28 No. 6, pp. $449-460$.

* Cohen, S., Mamakou, X.J. and Karatzimas, S. (2017), "IT-enhanced popular reports: analyzing citizen preferences", Government Information Quarterly, Vol. 34 No. 2, pp. 283-295.

* Cotterell, G. and Crothers, C. (2011), "Social indicators and social reporting in New Zealand, and the potential contribution of the Family Whānau and Wellbeing Project", Social Policy Journal of New Zealand, Vol. 37, pp. 152-171.

de Villiers, C. and Van Staden, C.J. (2011), "Where firms choose to disclose voluntary environmental information", Journal of Accounting and Public Policy, Vol. 30 No. 6, pp. 504-525.

de Villiers, C., Hsiao, P. and Maroun, W. (2017), "Developing a conceptual model of influences around integrated reporting, new insights, and directions for future research", Meditari Accountancy Research, Vol. 25 No. 4, pp. 450-460.

* Del Bello, A. (2006), "Intangibles and sustainability in local government reports: an analysis into an uneasy relationship", Journal of Intellectual Capital, Vol. 7 No. 4, pp. 440-456.

* Del Sordo, C., Farneti, F., Guthrie, J., Pazzi, S. and Siboni, B. (2016), "Social reports in Italian universities: disclosures and preparers' perspective", Meditari Accountancy Research, Vol. 24 No. 1, pp. 91-110.

Denyer, D. and Tranfield, D. (2006), "Using qualitative research synthesis to build an actionable knowledge base", Management Decision, Vol. 44 No. 2, pp. 213-227.

* Domingues, A.R., Lozano, R., Ceulemans, K. and Ramos, T.B. (2017), "Sustainability reporting in public sector organisations: exploring the relation between the reporting process and organisational change management for sustainability", Journal of Environmental Management, Vol. 192, May, pp. 292-301. 
Dumay, J. (2014), "15 years of the Journal of Intellectual Capital and counting: a manifesto for transformational IC research", Journal of Intellectual Capital, Vol. 15 No. 1, pp. 2-37.

* Dumay, J., Guthrie, J. and Farneti, F. (2010), "GRI sustainability reporting: guidelines for public and third sector organizations”, Public Management Review, Vol. 12 No. 4, pp. 531-548.

Dumay, J., Guthrie, J. and Puntillo, P. (2015), "IC and public sector: a structured literature review", Journal of Intellectual Capital, Vol. 16 No. 2, pp. 267-284.

Dumay, J., Bernardi, C., Guthrie, J. and Demartini, P. (2016), "Integrated reporting: a structured literature review", Accounting Forum, Vol. 40 No. 3, pp. 166-185.

* Farneti, F. and Siboni, B. (2011), "An analysis of the Italian governmental guidelines and of the local governments' practices for social reports”, Sustainability Accounting, Management and Policy Journal, Vol. 2 No. 1, pp. 101-125.

* Farneti, F., Casonato, F., Montecalvo, M. and de Villiers, C. (2019a), "The influence of integrated reporting and stakeholder information needs on the disclosure of social information in a state owned enterprise", Meditari Accountancy Research, Vol. 27 No. 4, pp. 556-579.

* Farneti, F., Guthrie, J. and Canetto, M. (2019b), "Social reports of an Italian provincial government: a longitudinal analysis", Meditari Accountancy Research, Vol. 27 No. 4, pp. 580-612.

* Ferrero-Ferrero, I., Fernández-Izquierdo, M., Muñoz-Torres, M. and Bellés-Colomer, L. (2018), "Stakeholder engagement in sustainability reporting in higher education: an analysis of key internal stakeholders' expectations", International Journal of Sustainability in Higher Education, Vol. 19 No. 2, pp. 313-336.

* Fonseca, A., Macdonald, A., Dandy, E. and Valenti, P. (2011), "The state of sustainability reporting at Canadian universities", International Journal of Sustainability in Higher Education, Vol. 12 No. 1, pp. 22-40.

* Frías-Aceituno, J.V., Rodríguez-Ariza, L. and González-Bravo, M.I. (2013), "The effect of societal values on local government transparency: applying Hofstede's cultural dimensions", Lex Localis, Vol. 11 No. 4, pp. 829-850.

* Frost, G.R. and Seamer, M. (2002), “Adoption of environmental reporting and management practices: an analysis of New South Wales public sector entities", Financial Accountability and Management, Vol. 18 No. 2, pp. 103-127.

* Fusco, F. and Ricci, P. (2019), "What is the stock of the situation? A bibliometric analysis on social and environmental accounting research in public sector", International Journal of Public Sector Management, Vol. 32 No. 1, pp. 21-41.

* Gamage, P. and Sciulli, N. (2017), "Sustainability reporting by Australian universities", Australian Journal of Public Administration, Vol. 76 No. 2, pp. 187-203.

* Garde-Sánchez, R., Rodríguez Bolívar, M.P. and Lopez-Hernández, A.M. (2017), "Corporate and managerial characteristics as drivers of social responsibility disclosure by state-owned enterprises", Review of Managerial Science, Vol. 11 No. 3, pp. 633-659.

Garfield, E. (1977), "Introducing citation classics: the human side of scientific reports", Current Contents, Vol. 1 No. 1, pp. 5-7.

* Giacomini, D., Rocca, L., Carini, C. and Mazzoleni, M. (2018), "Overcoming the barriers to the diffusion of sustainability reporting in Italian LGOs: better stick or carrot?", Sustainability, Vol. 10 No. 1, pp. 1-14.

* Gigli, S. and Tieghi, M. (2012), "The purposes of social accounting in Italian public health organizations”, Economic Research - Ekonomska istraživanja, Vol. 25 No. 3, pp. 846-868.

* Goswami, K. and Lodhia, S. (2014), "Sustainability disclosure patterns of South Australian local Councils: a case study", Public Money and Management, Vol. 34 No. 4, pp. 273-280.

* Greco, G., Sciulli, N. and D’Onza, G. (2012), "From Tuscany to Victoria: some determinants of sustainability reporting by local councils", Local Government Studies, Vol. 38 No. 5, pp. 681-705.
Non-financial reporting formats in

PSOs

665 
JPBAFM 32,4

* Greco, G., Sciulli, N. and D'Onza, G. (2015), "The influence of stakeholder engagement on sustainability reporting: evidence from Italian local councils", Public Management Review, Vol. 17 No. 4, pp. 465-488.

* Greiling, D., Traxler, A.A. and Stötzer, S. (2015), "Sustainability reporting in the Austrian, German and Swiss public sector", International Journal of Public Sector Management, Vol. 28 Nos 4/5, pp. 404-428.

GRI (Global Reporting Initiative) (2005), Sector Supplement for Public Agencies, Global Reporting Initiative, Amsterdam.

GRI (Global Reporting Initiative) (2010), GRI Reporting in Government Agencies, GRI, Amsterdam, available at: https://www.globalreporting.org/resourcelibrary/GRI-Reporting-in-GovernmentAgencies.

* Guthrie, J. and Farneti, F. (2008), "GRI sustainability reporting by Australian public sector organizations", Public Money and Management, Vol. 28 No. 6, pp. 361-366.

Guthrie, J., Petty, R. and Ricceri, F. (2006), "The voluntary reporting of intellectual capital: comparing evidence from Hong Kong and Australia", Journal of Intellectual Capital, Vol. 7 No. 2, pp. 254-271.

Guthrie, J., Ball, A. and Farneti, F. (2010), "Editorial: sustainability management of public and not for profit organisations", Public Management Review, Vol. 12 No. 4, pp. 449-459.

Guthrie, J., Ricceri, F. and Dumay, J. (2012), "Reflections and projections: a decade of intellectual capital accounting research", The British Accounting Review, Vol. 44 No. 2, pp. 68-92.

Hackston, D. and Milne, M. (1996), "Some determinants of social and environmental disclosures in New Zealand companies", Accounting, Auditing and Accountability Journal, Vol. 9 No. 1, pp. 77-108.

* Hossain, M.M. (2018), "Sustainability reporting by Australian local government authorities”, Local Government Studies, Vol. 44 No. 4, pp. 577-600.

* Huber, S. and Bassen, A. (2018), "Towards a sustainability reporting guideline in higher education", International Journal of Sustainability in Higher Education, Vol. 19 No. 2, pp. 218-232.

Iacuzzi, S., Garlatti, A., Fedele, P. and Lombrano, A. (2020), "Integrated reporting and change: evidence from public universities", Journal of Public Budgeting, Accounting \& Financial Management, Vol. 32 No. 2, pp. 291-310.

* Jordan, M.M., Yusuf, J.E., Berman, M. and Gilchrist, C. (2017), "Popular financial reports as fiscal transparency mechanisms: an assessment using the fiscal transparency index for the citizen user”, International Journal of Public Administration, Vol. 40 No. 8, pp. 625-636.

* Joseph, C., Pilcher, R. and Taplin, R. (2014), "Malaysian local government Internet sustainability reporting", Pacific Accounting Review, Vol. 26 Nos 1-2, pp. 75-93.

* Kansal, M., Joshi, M., Babu, S. and Sharma, S. (2018), "Reporting of corporate social responsibility in central public sector enterprises: a study of post mandatory regime in India", Journal of Business Ethics, Vol. 151 No. 3, pp. 813-831.

Kaur, A. and Lodhia, S.K. (2019), "Sustainability accounting, accountability and reporting in the public sector”, Meditari Accountancy Research, Vol. 27 No. 4, pp. 498-504.

* Kräusche, K. and Pilz, S. (2018), "Integrated sustainability reporting at HNE Eberswalde - a practice report", International Journal of Sustainability in Higher Education, Vol. 19 No. 2, pp. 291-312.

Krippendorff, K. (2013), Content Analysis. An Introduction to its Methodology, Sage Publications, Thousand Oaks, CA.

Lakshman, C. (2012), "Structured content analysis in leadership research: a new method for international contexts", The Leadership and Organization Development Journal, Vol. 33 No. 5, pp. $477-493$.

* Larrinaga, C., Luque-Vilchez, M. and Fernández, R. (2018), "Sustainability accounting regulation in Spanish public sector organizations", Public Money and Management, Vol. 38 No. 5, pp. 345-354. 
* Larrinaga-Gonzélez, C. and Pérez-Chamorro, V. (2008), "Sustainability accounting and accountability in public water companies", Public Money and Management, Vol. 28 No. 6, pp. 337-343.

Liu, Z., Jubb, C. and Abhayawansa, S. (2019), "Analysing and evaluating integrated reporting: insights from applying a normative benchmark", Journal of Intellectual Capital, Vol. 20 No. 2, pp. 235-263.

* Lodhia, S. and Jacobs, K. (2013), "The practice turn in environmental reporting: a study into current practices in two Australian commonwealth departments", Accounting, Auditing and Accountability Journal, Vol. 26 No. 4, pp. 595-615.

* Lodhia, S., Jacobs, K. and Park, Y.J. (2012), "Driving public sector environmental reporting: the disclosure practices of Australian commonwealth departments", Public Management Review, Vol. 14 No. 5, pp. 631-647.

* Lopatta, K. and Jaeschke, R. (2014), "Sustainability reporting at German and Austrian universities", International Journal of Education Economics and Development, Vol. 5 No. 1, pp. 66-90.

* Lopez, Y.P. and Martin, W.F. (2018), "University mission statements and sustainability performance", Business and Society Review, Vol. 123 No. 2, pp. 341-368.

* Lozano, R. (2011), "The state of sustainability reporting in universities", International Journal of Sustainability in Higher Education, Vol. 12 No. 1, pp. 67-78.

* Lubinger, M., Frei, J. and Greiling, D. (2019), "Assessing the materiality of university G4sustainability reports", Journal of Public Budgeting, Accounting and Financial Management, Vol. 31 No. 3, pp. 364-391.

* Madeira, A.C., Carravilla, M.A., Oliveira, J.F. and Costa, C.A. (2011), "A methodology for sustainability evaluation and reporting in higher education institutions", Higher Education Policy, Vol. 24 No. 4, pp. 459-479.

* Manes-Rossi, F. (2019), "New development: alternative reporting formats: a panacea for accountability dilemmas?", Public Money and Management, Vol. 39 No. 7, pp. 528-531.

Manes-Rossi, F., Nicolò, G. and Tartaglia Polcini, P. (2018), "New trends in intellectual capital reporting: exploring online intellectual capital disclosure in Italian universities", Journal of Intellectual Capital, Vol. 19 No. 4, pp. 1469-1930.

* Manes-Rossi, F., Aversano, N. and Tartaglia Polcini, P. (2020), "Popular reporting: learning from the US experience", Journal of Public Budgeting, Accounting and Financial Management, Vol. 32 No. 1, pp. 92-113.

* Marcuccio, M. and Steccolini, I. (2005), "Social and environmental reporting in local authorities: a new Italian fashion?”, Public Management Review, Vol. 7 No. 2, pp. 155-176.

* Marcuccio, M. and Steccolini, I. (2009), "Patterns of voluntary extended performance reporting in Italian local authorities", International Journal of Public Sector Management, Vol. 22 No. 2, pp. 146-167.

Massaro, M., Dumay, J. and Garlatti, A. (2015), "Public sector knowledge management: a structured literature review", Journal of Knowledge Management, Vol. 19 No. 3, pp. 530-558.

Massaro, M., Dumay, J. and Guthrie, J. (2016), "On the shoulders of giants: undertaking a structured literature review in accounting”, Accounting, Auditing and Accountability Journal, Vol. 29 No. 5, pp. 767-801.

* Mazzara, L., Sangiorgi, D. and Siboni, B. (2010), "Public strategic plans in Italian local governments: a sustainability development focus?”, Public Management Review, Vol. 12 No. 4, pp. 493-509.

Merchant, K.A. and Van der Stede, W.A. (2007), Management Control Systems. Performance Measurement, Evaluation and Incentives, 2nd ed., Pearson Education, Harlow.

* Monfardini, P., Barretta, A.D. and Ruggiero, P. (2013), "Seeking legitimacy: social reporting in the healthcare sector", Accounting Forum, Vol. 37 No. 1, pp. 54-66.

* Montecalvo, M., Farneti, F. and De Villiers, C. (2018), "The potential of integrated reporting to enhance sustainability reporting in the public sector", Public Money and Management, Vol. 38 No. 5, pp. 365-374.
Non-financial reporting formats in

PSOs

667 
JPBAFM 32,4

Mulrow, C.D., Cook, D.J. and Davidoff, F. (1997), "Systematic reviews: critical links in the great chain of evidence", Annals of Internal Medicine, Vol. 126, pp. 389-391.

* Mussari, R. and Monfardini, P. (2010), "Practices of social reporting in public sector and non-profit organizations: an Italian perspective", Public Management Review, Vol. 12 No. 4, pp. 487-492.

* Navarro-Galera, A., De Los Ríos-Berjillos, A., Lozano, M.R. and Valencia, P.T. (2014), "Transparency of sustainability information in local governments: English-speaking and Nordic cross-country analysis", Journal of Cleaner Production, Vol. 64, pp. 495-504.

* Navarro-Galera, A., Alcaraz-Quiles, F.J. and Ortiz-Rodríguez, D. (2016), "Online dissemination of information on sustainability in regional governments. Effects of technological factors", Government Information Quarterly, Vol. 33 No. 1, pp. 53-66.

* Niemann, L. and Hoppe, T. (2018), "Sustainability reporting by local governments: a magic tool? Lessons on use and usefulness from European pioneers", Public Management Review, Vol. 20 No. 1, pp. 201-223.

* Ortiz-Rodríguez, D., Navarro-Galera, A. and Alcaraz-Quiles, F.J. (2018), "The influence of administrative culture on sustainability transparency in European local governments", Administration and Society, Vol. 50 No. 4, pp. 555-594.

Petticrew, M. and Roberts, H. (2008), Systematic Reviews in the Social Sciences: A Practical Guide, Kindle ed., Wiley-Blackwell, Oxford.

* Rahaman, A.S., Lawrence, S. and Roper, J. (2004), "Social and environmental reporting at the VRA: institutionalised legitimacy or legitimation crisis?", Critical Perspectives on Accounting, Vol. 15 No. 1, pp. 35-56.

* Romolini, A., Fissi, S. and Gori, E. (2015), "Quality disclosure in sustainability reporting: evidence from universities", Transylvanian Review of Administrative Science, Vol. 11 No. 44, pp. 196-218.

* Ruiz-Lozano, M., Navarro-Galera, A., Tirado-Valencia, P. and De Los Ríos-Berjillos, A. (2019), "Can the cultural environment affect governmental transparency on sustainability? Useful measures for policy makers and practitioners", Local Government Studies, Vol. 45 No. 4, pp. 481-503.

* Samkin, G. (2012), "Changes in sustainability reporting by an African defence contractor: a longitudinal analysis", Meditari Accountancy Research, Vol. 20 No. 2, pp. 134-166.

* Sangiorgi, D. and Siboni, B. (2017), "The disclosure of intellectual capital in Italian universities: what has been done and what should be done", Journal of Intellectual Capital, Vol. 18 No. 2, pp. 354-372.

* Sangiorgi, D., Mazzara, L. and Siboni, B. (2017), "Do European recommendations impact on sustainability policies by Italian local governments?", Public Money and Management, Vol. 37 No. 7, pp. 491-498.

Santis, S., Grossi, G. and Bisogno, M. (2018), "Public sector consolidated financial statements: a structured literature review", Journal of Public Budgeting, Accounting and Financial Management, Vol. 30 No. 2, pp. 230-251.

* Sassen, R. and Azizi, L. (2018), “Assessing sustainability reports of US universities”, International Journal of Sustainability in Higher Education, Vol. 19 No. 7, pp. 1158-1184.

* Sassen, R., Dienes, D. and Wedemeier, J. (2018), "Characteristics of UK higher education institutions that disclose sustainability reports", International Journal of Sustainability in Higher Education, Vol. 19 No. 7, pp. 1279-1298.

Scapens, R.W. (1990), "Research in management accounting practice: the role of case study methods", The British Accounting Review, Vol. 22 No. 3, pp. 259-281.

* Schaffhauser-Linzatti, M. and Ossmann, S. (2018), "Sustainability in higher education's annual reports: an empirical study on Australian and Austrian universities", International Journal of Sustainability in Higher Education, Vol. 19 No. 2, pp. 233-248.

* Sciulli, N. (2011), "The views of managers from a local coastal council on sustainability reporting issues: an Australian-based case study", Qualitative Research in Accounting and Management, Vol. 8 No. 2, pp. 139-160. 
* Seibert, R. and Macagnan, C. (2019), "Social responsibility disclosure determinants by philanthropic higher education institutions", Meditari Accountancy Research, Vol. 27 No. 2, pp. 258-286.

* Sepasi, S., Braendle, U. and Rahdari, A. (2019), "Comprehensive sustainability reporting in higher education institutions", Social Responsibility Journal, Vol. 15 No. 2, pp. 155-170.

* Siboni, B., del Sordo, C. and Pazzi, S. (2013), "Sustainability reporting in state universities: an investigation of Italian pioneering practices", International Journal of Social Ecology and Sustainable Development, Vol. 4 No. 2, pp. 1-15.

Steccolini, I. (2019), "Accounting and the post-new public management: re-considering publicness in accounting research", Accounting, Auditing and Accountability Journal, Vol. 32 No. 1, pp. 255-279.

Szejnwald Brown, H.S., de Jong, M. and Lessidrenska, T. (2009), "The rise of GRI: a case of institutional entrepreneurship", Environmental Politics, Vol. 18 No. 2, pp. 182-200.

* Tirado-Valencia, P., Cordobés-Madueño, M., Ruiz-Lozano, M. and De Vicente-Lama, M. (2019), "Integrated thinking in the reporting of public sector enterprises: a proposal of contents", Meditari Accountancy Research, Vol. 28 No. 3, pp. 435-453.

Tranfield, D., Denyer, D. and Smart, P. (2003), "Towards a methodology for developing evidence informed management knowledge by means of systematic review", British Journal of Management, Vol. 14 No. 3, pp. 207-222.

* Uyar, A., Kuzey, C. and Kilic, M. (2019), "Testing the spillover effects of sustainability reporting: evidence from the public sector", International Journal of Public Administration. doi: 10.1080/ 01900692.2019.1677711, forthcoming.

* Veltri, S. and Silvestri, A. (2015), "The Free State University integrated reporting: a critical consideration", Journal of Intellectual Capital, Vol. 16 No. 2, pp. 443-462.

* Vinnari, E. and Laine, M. (2013), "Just a passing fad?: the diffusion and decline of environmental reporting in the Finnish water sector", Accounting, Auditing and Accountability Journal, Vol. 26 No. 7, pp. 1107-1134.

* Williams, B., Wilmshurst, T. and Clift, R. (2011), "Sustainability reporting by local government in Australia: current and future prospects", Accounting Forum, Vol. 35 No. 3, pp. 176-186.

* Yáñez, S., Uruburu, A., Moreno, A. and Lumbreras, J. (2019), "The sustainability report as an essential tool for the holistic and strategic vision of higher education institutions", Journal of Cleaner Production, Vol. 207, pp. 57-66.

Yin, R.K. (2014), Case Study Research. Design and Methods, 5th ed., SAGE, Los Angeles, CA.

* Zhao, N. and Patten, D.M. (2016), "An exploratory analysis of managerial perceptions of social and environmental reporting in China: evidence from state-owned enterprises in Beijing", Sustainability Accounting, Management and Policy Journal, Vol. 7 No. 1, pp. 80-98.

* Zorio-Grima, A., Sierra-García, L. and Garcia-Benau, M. (2018), "Sustainability reporting experience by universities: a causal configuration approach", International Journal of Sustainability in Higher Education, Vol. 19 No. 2, pp. 337-352.

\section{Corresponding author}

Giuseppe Nicolò can be contacted at: gnicolo@unisa.it
Non-financial reporting formats in

PSOs 